\title{
Biocultural Diversity of the Endemic 'Wild Jack Tree' on the Malabar Coast of South India
}

\author{
Sam P. Mathew, A. Mohandas, S. M. Shareef and G. M. Nair
}

\section{Research}

\begin{abstract}
Artocarpus hirsutus Lam. is an endemic tree species of the southern Western Ghats of Peninsular India. It is popularly known as the "wild jack tree". Several attributes in art, culture and socio-economic civilization among the folk communities in Kerala state (Malabar coast) distinguish the tree in the history of Indian civilization. Most of the traditional uses and indigenous know-how earlier referred to this species are vanishing. This article discusses various aspects of the popular wild jack tree of the Malabar coast and its vanishing indigenous biocultural diversity among the folk communities of the region.
\end{abstract}

\section{Introduction}

Cultural and social attributes of human communities have substantial influence on biodiversity conservation and sustainable utilization of genetic resources. In India, there are biological species closely interlinked with religious and other ancient traditions. These have involved co-evolution of cultural traditions with selection of wild plant species. Most of such species among Indian communities have divine status and are thus conserved for the sake of spiritual beliefs, and religious worship. 'Vricksha Ayurveda' (Arboreal medicine) and 'Vricksha Pooja' (Arboreal worship) are ancient Indian texts describing methods that result in sustainable utilization and conservation of tree species. These have been employed since the Vedic period of Indian civilization. The twelve chapters of Vricksha Ayurveda refer to methods of plant introduction, soil classification, propagation techniques, garden development, conservation and preservation techniques for different species including those around homesteads (Rajashekharan \& Pushpangadan1993). Similarly, Vricksha Pooja is an ancient Indian ritual connected with felling trees that dealt with the sustainable utilization of tree species for timber. Although several indigenous and endemic plants have had remarkable influences on Indian traditions, uses and indigenous knowledge of 'narrow endemic species' is lesser known to the modern world.

The Western Ghats mountain range runs parallel to the West coast of Peninsular India for about 1,600 km and covers a biogeographical region of $160,000 \mathrm{~km}^{2}$. It is a very rich phytogeographical zone with 4000 indigenous Angiosperm species, which includes 1,500 endemic species. Of these, 1215 (352 endemic) species are trees (Ramesh \& Pascal1997). The tropical rain forests occurring on the slopes of these mountain ranges are of Gondwana landmass origin (Nayar 1996). They are anthropogenically disturbed in many regions, with many of disturbance regimes presumably following recommendations of the Vricksha Ayurveda and Vricksha Pooja.

\section{The Wild Jack Tree}

The wild jack tree, Artocarpus hirsutus Lam (Moraceae), is one of the endemic timber species of the southern Western Ghats. It is especially popular along the Malabar coast. The tree is reported in early scientific literature in

\section{Correspondence}

Sam P. Mathew, A. Mohandas, S. M. Shareef and G. M. Nair Tropical Botanic Garden and Research Institute, Palode, Thiruvananthapuram 695 562, Kerala State, INDIA.

S.P. Mathew, sampmatthew@rediffmail.com

A. Mohandas, dr_mohandas@yahoo.co.in

S.M. Shareef, shariftbgri@rediffmail.com

G.M. Nair, gmnair@rediffmail.com

Ethnobotany Research \& Applications 4:025-040 (2006) 


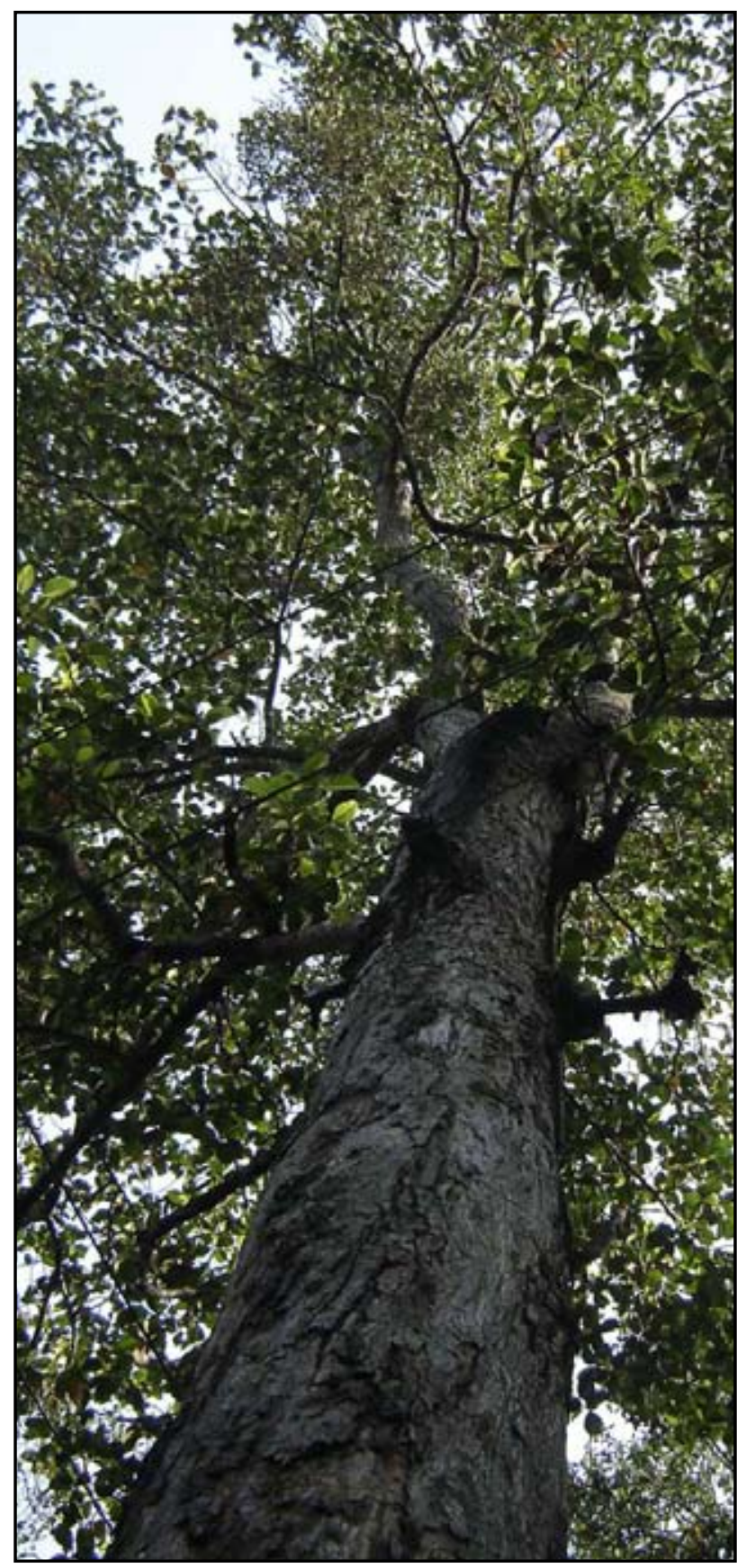

Figure 1. The wild jack tree (Artocarpus hirsutus Lam.) of the Malabar coast.

Hortus Indicus Malabaricus' (Rheede 1682). It is one of the best commercial timber species. Under British colonial governments, the Royal Forest Department classified the status of the timber next to the royal timbers teak, rosewood, sandalwood and ebony. However, from the local utilization point of view, $A$. hirsutus is the most popular timber species along the Malabar coast. Better timber quality and lower cost may be the reasons for this. According to current information, there are 18 species of $\mathrm{Ar}$ - tocarpus reported from India but $A$. hirsutus is the only endemic species (Ahmedulla \& Nair 1977). This handsome tree is considered as one of the 'keystone species' of the Western Ghats (Nayar 1996), reaching a height up to 45 $\mathrm{m}$ with girth up to $4.5 \mathrm{~m}$ in moist evergreen forests. It is found from sea level to $1000 \mathrm{~m}$ altitude where there is an average annual rainfall of $1500 \mathrm{~mm}$ with sandy and rocky soils. The ripe fruit are eaten by several birds, monkeys, squirrels, and slender loris (Loris lyddekerianus malabaricus). From an economic point of view, $A$. hirsutus usually attains maturity for timber extraction within the period of 25 to 40 years. The trees growing near backwaters and lagoons grow much faster and attain maximum girth within the shorter period of the range.

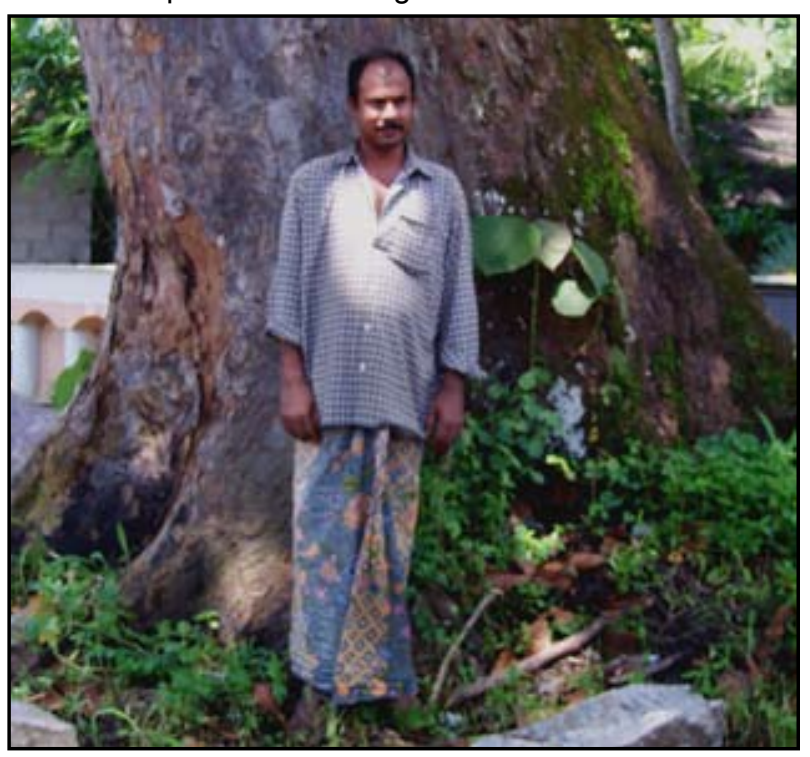

Figure 2. Base portion of a wild jack tree.

\section{Wood morphology and anatomy}

The sapwood is white, $10-15 \mathrm{~cm}$ thick. The heartwood is bright or golden yellow, which darkens rapidly to russet then slowly to dark walnut or blackish brown after a few hours exposure to sunlight. Often the aged wood developed darker lines as well. Usually the wood is straight without knots and very similar to teak in strength and other properties. However, unlike Teak or Rosewood, the growth rings of this species are scarcely distinct. The timber is very durable even when in contact with saline water and not susceptible to white ants or fungal attacks (Pearson \& Brown 1932). Air-seasoning of wood is the traditional method to prevent splitting and surface cracks.

The wood anatomy of $A$. hirsutus shows much similarity to Artocarpus chaplasha. However, $A$. hirsutus is darker in colour and coarser-textured with larger or sometimes medium sized vessels and narrow aureoles of paratracheal-zonate thin walled parenchyma and narrow lower rays. Tyloses are abundant in all vessels of heartwood, yellowish-brown in colour, thin walled and with simple pits. 


\section{Mathew et al. - Biocultural Diversity of the Endemic 'Wild Jack Tree' on the Malabar Coast of South India}

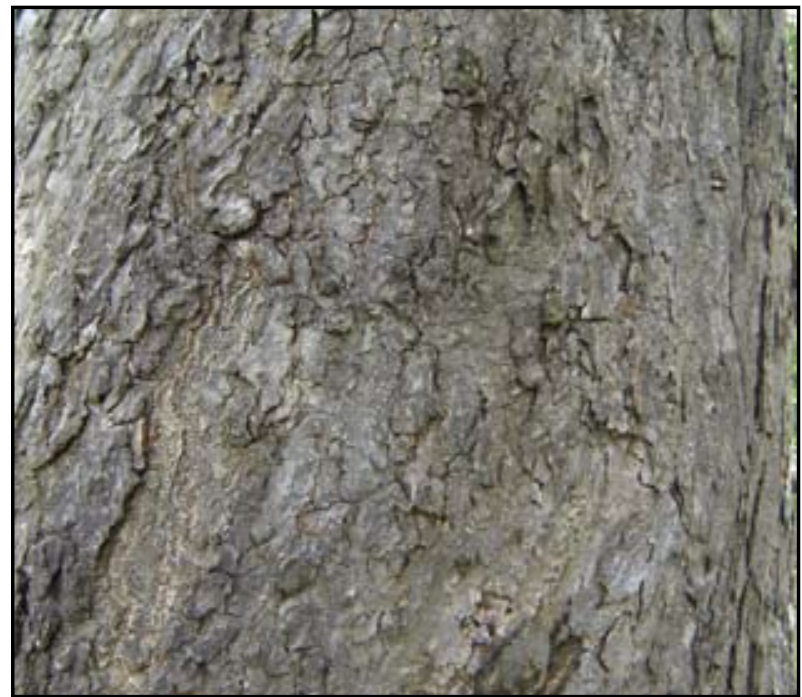

Figure 3. Bark of a mature wild jack tree.

White or yellowish-white chalky inclusions are present in many vessels. Indication of seasonal growth is indistinct in wood anatomy of the species. Intervessel pits are numerous, oval or elliptical, horizontally aligned and crowded. Gummy infiltration is absent. However, white or yellowish-white chalky inclusions are found in many vessels. Fibers are non-libriform, medium coarse appearing rather angled in transverse section and smaller than parenchyma cells aligned in radial rows. Fibers are found in some tracts much thicker than others. Abundant inter-fiber pits are mostly confined to radial walls. Rays are rather medium coarse appearing as radial lines in the wood which curve around the larger vessels, frequently penetrating the aureoles of paratracheal pranchyma and rarely contiguous to the vessels. Rays are seriate and heterogeneous. Broad rays are 2 to 5 seriate mostly with 'horizontal' cells and occasionally with 'upright' cells along the flanks. The narrow rays are one to two seriate rather less than the former wholly of 'upright' cells or 'horizontal' cells. Crystals, starch deposits and gummy infiltrations are absent. How-

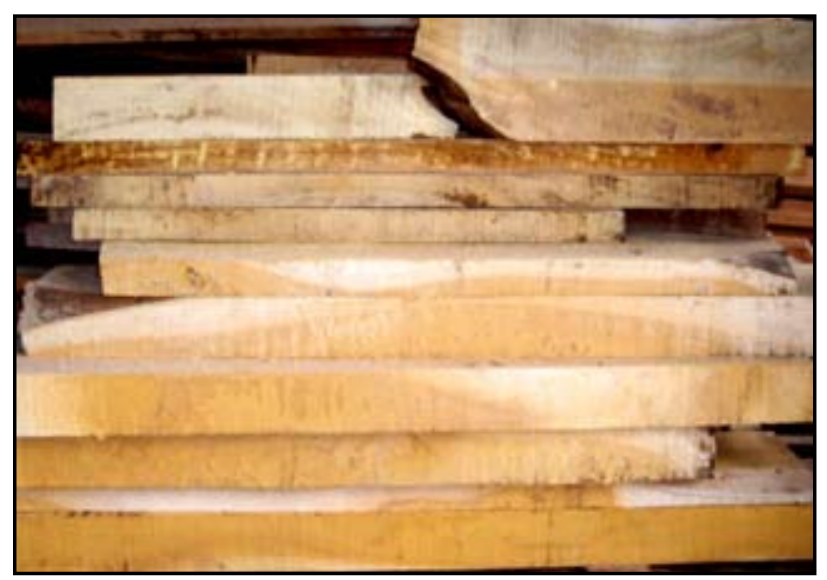

Figure 4. Bright yellow colored wild jack timber immediately after sawing.

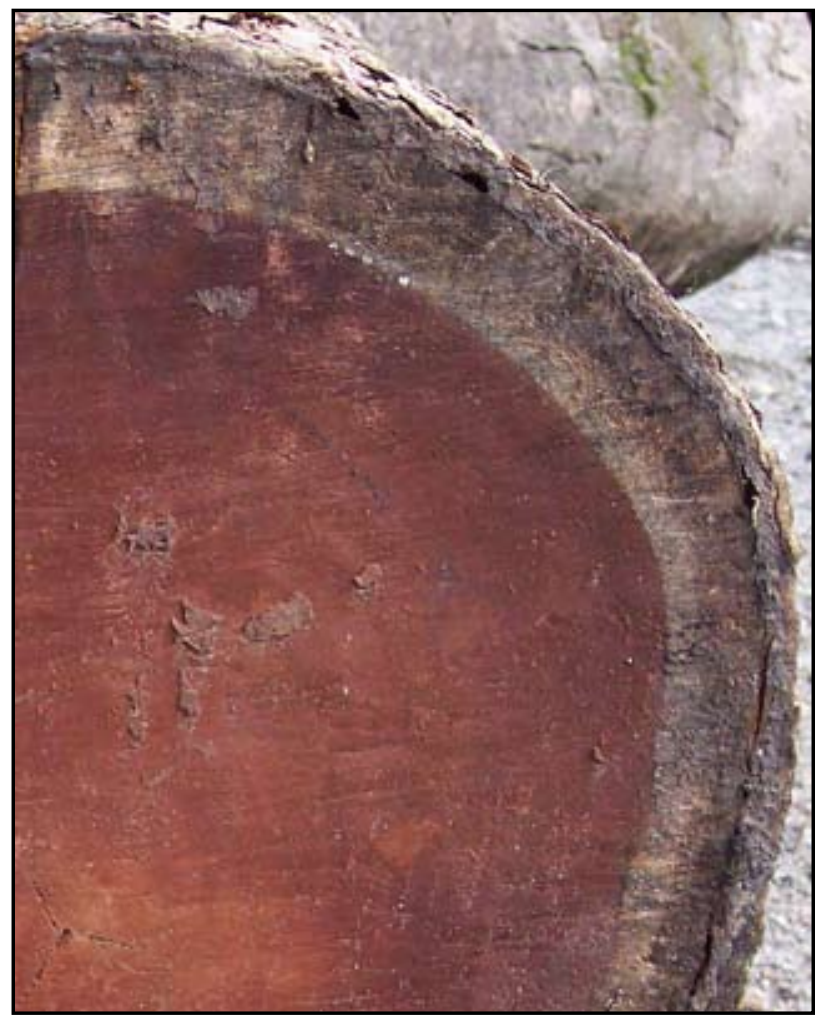

Figure 5. Cut trunk of wild jack tree exposed to sun light turned into dark walnut brown.

ever, white chalky infiltrations similar to the case of vessels are rarely present.

\section{Propagation and cultivation}

Usually the trees growing in open space with crowns exposed to sunlight bear more fruit (Rai 1978). Normally about 2000 viable seeds weigh one kilogram (Rai 1978).

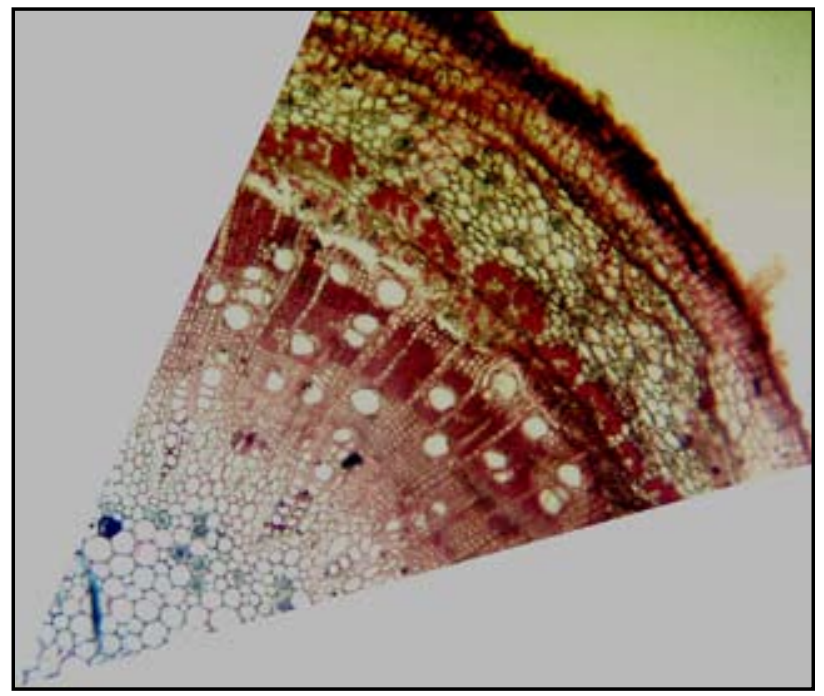

Figure 6. Cross section of wild jack wood. 
The viability of seeds is comparatively lesser than three weeks (Rai 1978). The seeds for germination trials should be selected from mature ripe normal sized fruit and properly washed to remove the pulpy perianth before germination trials. Generally, the germination rate ranges from 80 to $85 \%$ (Rai 1978). The seeds can be sown either in raised shaded germination beds or in poly bags and under shade. The shade condition for 2 to 3 months to seedlings can activate faster growth. It is also advisable to mulch with leaf litter to reduce impact of rain. The juvenile deeply lobed leaves (pinnatifid) of the seedlings are later replaced by normal simple leaves. The seedlings may remain in two-leaved condition for a period of 15 to 20 days. The field transplantation can effectively be carried out with one-year-old seedlings. Experiments have shown that stump planting is also another good method for propagation of $A$. hirsutus followed by dibbling and planting of bare rooted seedlings (Rai 1978). The best season for field planting of seedlings is during the onset of southwest monsoon. Usually the shoot growth is double the root growth in earlier stages. The primary roots are usually thicker than the shoots at the collar level. Lateral roots are few, moderately long and thin while the taproot is strong and straight. Shade and light are very essential for the better growth of the seedlings. Usually seedlings planted in moist areas with adequate light, shade have better growth rate and root growth is faster under nursery condition than in the wild (Rai 1978).

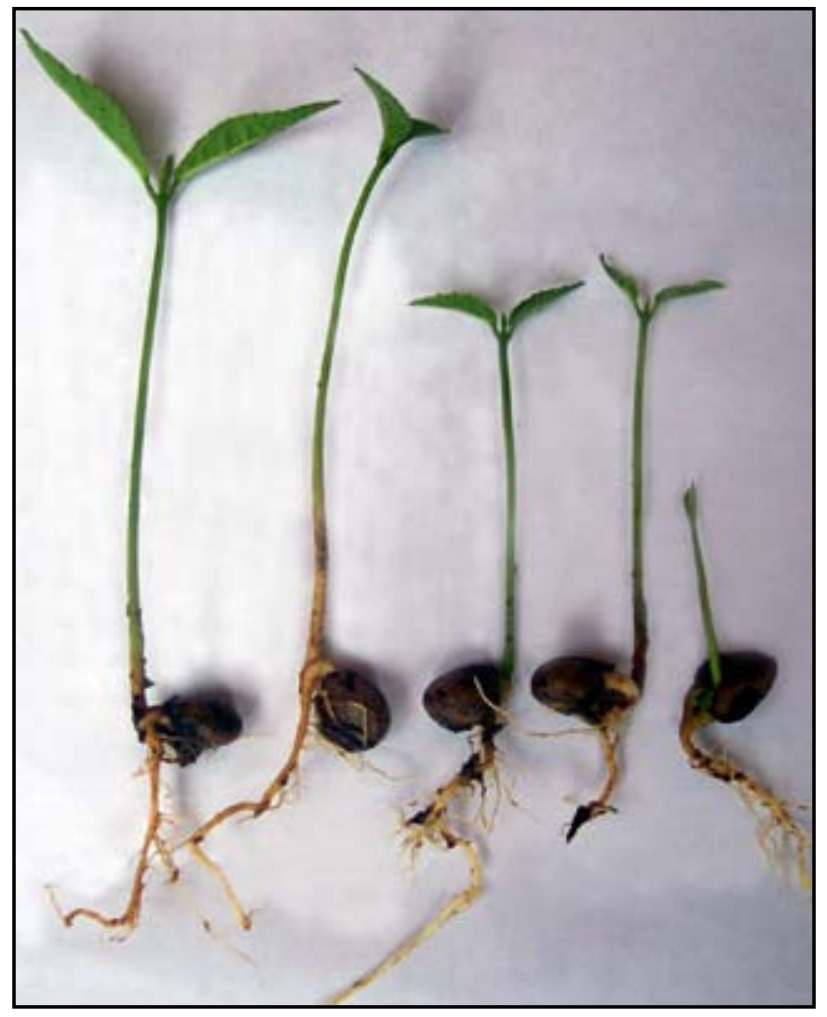

Figure 8. Wild jack tree seedlings.

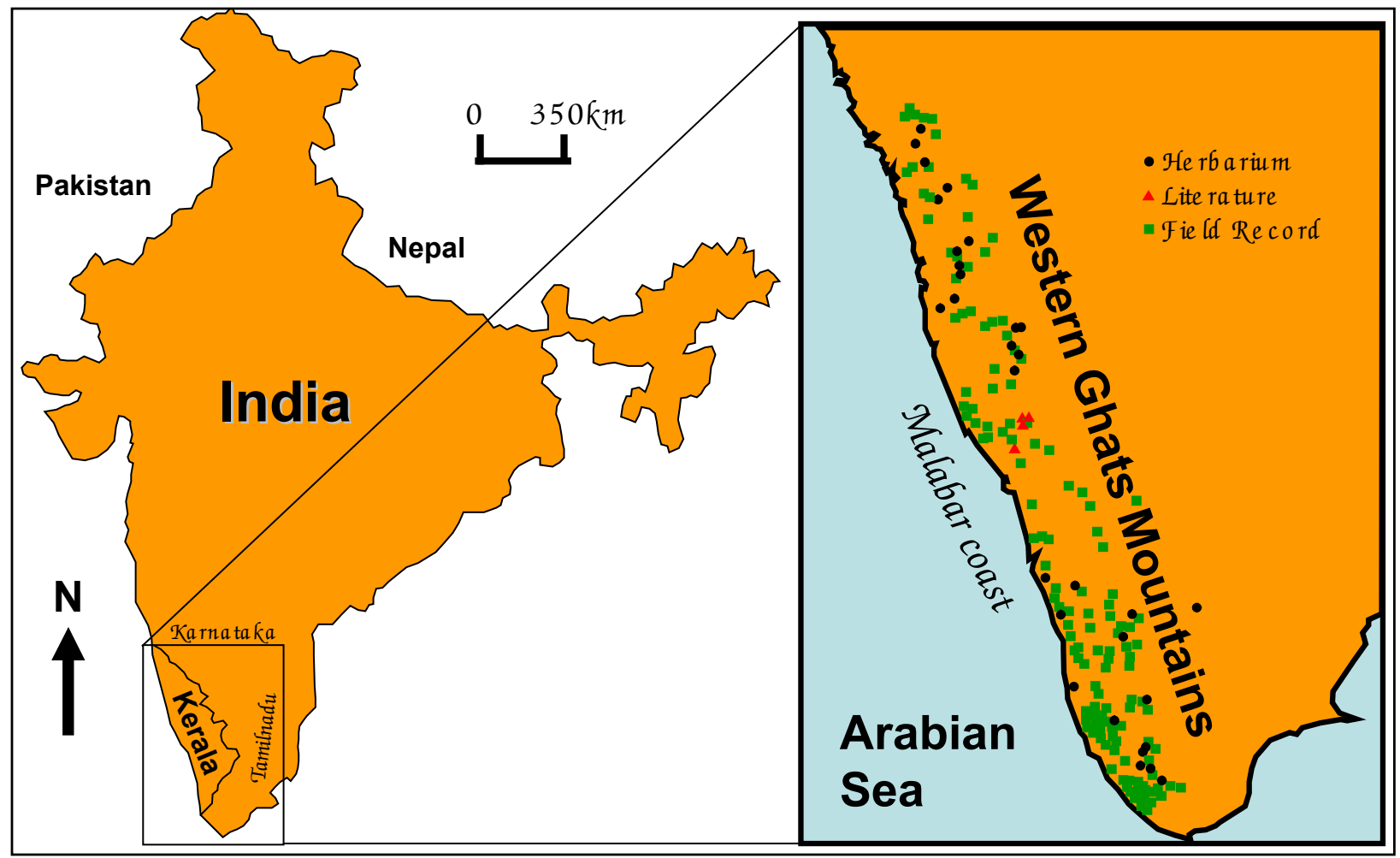

Figure 7. Geographical distribution of wild jack tree in Kerala State, India. 

Malabar Coast of South India

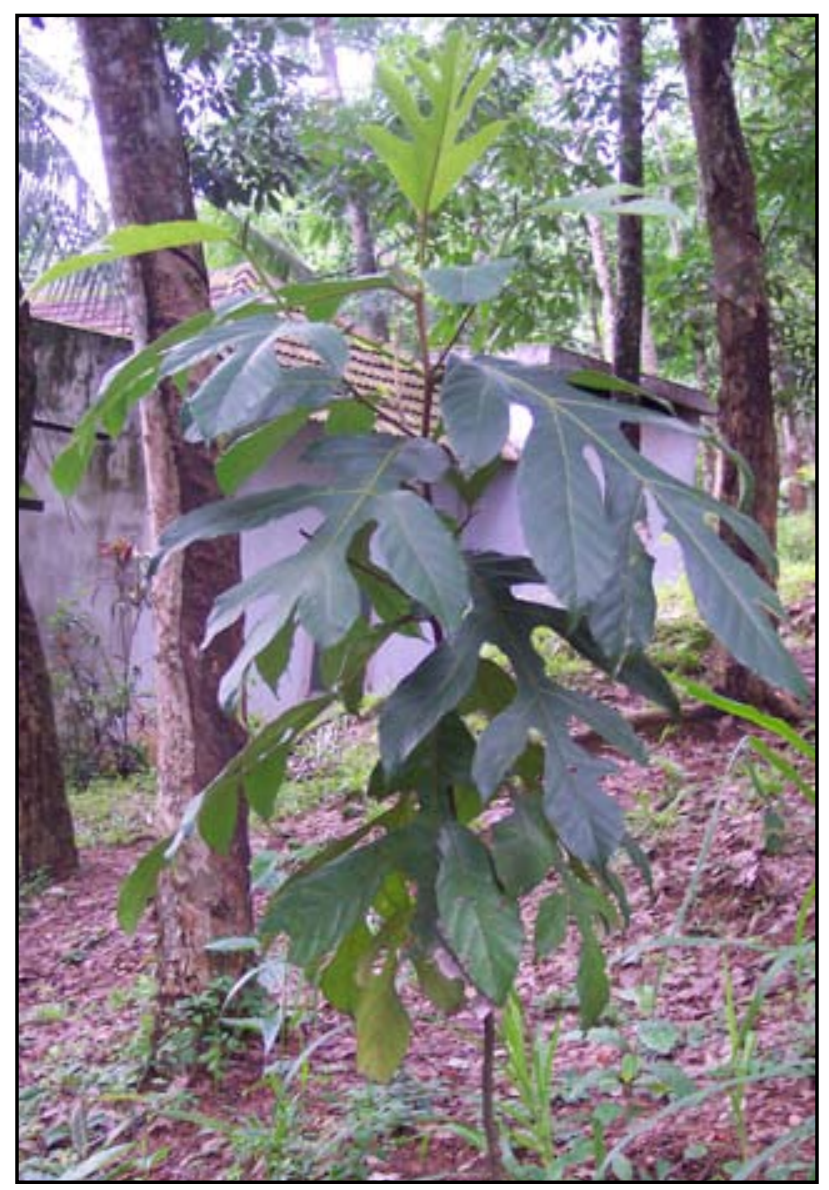

Figure 9. A juvenile wild jack tree with dissected leaves.

\section{Geographical distribution and vernacular names}

Artocarpus hirsutus is geographically restricted to the southern Western Ghats from the Kalinadi river of Maharashtra State in the north to the Agasthyamala in Thiruvananthapuram district of the Kerala State in the south (Ramesh \& Pascal 1997). However, the maximum frequency in geographical distribution is found to occur along the Malabar coast. Hence it has a remarkable influence in the cultural diversity and folklore of the Kerala, rather than any other folk communities in other states of the Indian Union. The wild jack tree has several vernacular names in different States (Table 1). In the 1600s this tree species was referred to as Ansjeli by Malabaris, Angeli by the Portuguese and Anjeli by the Belgians (van Rheede 1682).

Table 1. Artocarpus hirsutus vernacular names in India.

\begin{tabular}{|l|l|}
\hline State & Vernacular \\
\hline Karnataka & Hebbalasu \\
\hline Kerala & Anjalee, Aiyanee \\
\hline Maharastra & Pat pahnnas \\
\hline Tamilnadu & Anjale \\
\hline
\end{tabular}

\section{Historical Scenario of Wild Jack Tree in Kerala}

Kerala, the toponym derived from 'land of coconut palms', is a sea-gifted land according to Hindu mythology. Geographically, Kerala is a land of tropical rivers, mountains and seacoast, covering an area of about $38,828 \mathrm{~km}^{2}$ between $8^{\circ} 18^{\prime}$ and $12^{\circ} 48^{\prime} \mathrm{N}$ latitude and $74^{\circ} 54^{\prime}$ and $77^{\circ} 22^{\prime}$ $E$ longitude. The climate is warm-humid with strong influences of both southwest and northeast monsoons contributing to luxuriant growth of vegetation and rich plant diversity.

\section{Endogenous scenario}

In the past, the population of Kerala was a mixed group of Dravidians, Aryans and Negritoids. The Dravidians, with their cultural peculiarities and biological conservation point of view, were dominant. Dravidian culture is noted for sober temple architecture of indigenous wood works and wood carvings. The timber of wild jack tree is much used along with teak and rosewood in temples and old Christian churches in mural traditions of Kerala. Medicinal and aromatic plants including Aegle marmelos (L.) Corr. Serr., Ficus religiosa L. Michelia champaca L., Ocimum tenuiflorum L. and Saraca indica L. are enshrined in temples and homesteads as a part of cultural and religious traditions of the various Hindu communities of Kerala.

Conservation of 'sacred groves and watersheds' locally known as kavum kulavum (kavu = sacred grove; kulam = watershed) as a part of the religious belief by the Hindu communities of Kerala indicates another example of the antiqueness and heritage of their biocultural diversity. The sacred groves are 'relics' of primary forests of typical lowland evergreen type conserving as an ancient religious practice. These tracts of forests consist of several tiers of trees and shrubs with epiphytes, lianas and herbs and are associated with Hindu temples, famous Hindu family mansions and rarely even associated with Muslim family mansions also in some regions of Kerala. Snake worship (naga pooja) is a part of Dravidian culture and in most of the sacred groves snakes are being worshiped. This vegetational type and watersheds have ideal niches for reptiles like snakes, lizards, several kinds of birds and small animals to co-exist and these creatures are also being conserved as a part of sanctity of sacred groves. Presently Kerala has more than 1500 sacred groves with areas varying from $35 \mathrm{~m}^{2}$ to several hectares. Other gods in sacred groves who are being worshiped are Bhagavathi, Sastha, Shiva and Vishnu. Artocarpus hirsutus, which usually constitutes the top storey of the canopy, is one of the common species found to have been conserved in almost all sacred groves of Kerala (Rajendraprasad 1995). Usually the idols of various gods and goddesses are kept under this kind of tall tree in the sacred groves on a platform of granite stones for 'pooja' or worship. 


\section{Exogenous scenario}

The Arabian Sea and the spice plant species of Kerala, especially pepper (Piper nigrum L.) and cardamom (Elettaria cardamomum (L.) Maton), have remarkably influenced the turbulent history of Kerala. In very ancient times ( 2900 BC), Queen Sheba of Arabia presented ivory and spices possibly brought from Malabar to King Solomon of Israel (Bible 1984, 1 Kings 10). Kerala's maritime interactions of commerce and trade with Arabs date back to two millennia (Panikkassery 2001). Kerala became very popular among geographers and sailors centuries ago as the Malabar or spice coast of India. Europeans had no direct commercial connections with Kerala until the arrival of Pedro de Kovil Ho, who landed along with Arab merchants at Cannanore in 1488 (Panikkassery 2001) and Vasco de Gama who landed at the Kappad Beach (Calicut) of Malabar in 1498 (Panikkassery 2001). A series of European trading countries concluded with the British conquering the region in the latter part of the 18th century (Panikkassery 2001). Contact with Europeans, even though loaded with conflict, from a botanical point of view had significant influence and innovations in cultivation and agriculture through the introduction of new plant species including cashew (Anacardium occidentale L.), rubber (Hevea brasiliensis (A. Juss.) Muell. Arg.), chilli (Capsicum annuum. L.), cassava (Manihot esculenta Crantz), and many other New World species.

The commercial trade history of $A$. hirsutus dates back to the period of interactions between the Arabs and Keralites before to the arrival of Europeans. The durable timber was widely used by Arabs for cargo shipbuilding and their vessels carried teak and wild jack wood as far away as Europe. The Beypore port and shipyard of Malabar was very famous for cargo shipbuilding even two millennia ago. The coastal belt of Kerala is a narrow strip of lowland and very picturesque with extensive backwaters, lakes and lagoons flanked by coconut groves and paddy fields. The rivers and lagoons were significant in earlier civilization for inland transportation and commerce of the coastal zones. Boats used were likely mostly constructed $A$. hirsutus timber. These country boats ranged in size and shape depending on need and resources. Very small size boats suitable for a single person could be made from a single bole of wild jack. At the other extreme 500 ton capacity cargo boats for inland transportation were also made.

\section{Wild Jack Tree and Biocultural Diversity}

The wild jack tree has had much influence in the routine life of people of Kerala state from time immemorial. In addition to the uses of wood, the fruit and roasted seeds were eaten by poor villagers as a staple food until the latter half of the 20th century. Presently, the scarcity of trees, changing social status, advanced health care, development of technology and several other changes have al- tered these and other traditional uses such that they are no longer part of routine life of Keralites.

\section{Healthcare}

A variety of medicinal uses have been reported in the literature (Table 2). Generally few people still use wild jack trees for medicinal purposes but the uses that were developed may be seen as indicators of the importance of the trees in the past.

Table 2. Reported medicinal uses of wild jack tree.

\begin{tabular}{|c|c|}
\hline Part & Indication \\
\hline $\begin{array}{l}\text { bark } \\
\text { (ash) }\end{array}$ & $\begin{array}{l}\text { mixed with coconut oil is used externally } \\
\text { against 'dhobi's itch' and ringworm. (Geetha } \\
\text { et al. 1996) }\end{array}$ \\
\hline \multirow[t]{2}{*}{$\begin{array}{l}\text { bark } \\
\text { (paste) }\end{array}$} & $\begin{array}{l}\text { in coconut oil also can apply for snake bite. } \\
\text { (Parinitha et al. 2004) }\end{array}$ \\
\hline & $\begin{array}{l}\text { domestic animal bone fractures: mixed with } \\
\text { palm sugar made into a thick paste on frac- } \\
\text { ture (Geetha et al. 1996). }\end{array}$ \\
\hline $\begin{array}{l}\text { leaves } \\
\text { (dried) }\end{array}$ & joint pain and rigidity (van Rheede 1682) \\
\hline \multirow[t]{2}{*}{ leaves } & $\begin{array}{l}\text { crushed with turmeric (Curcuma longa L.) can } \\
\text { treat chronic hemorrhage with continuous ap- } \\
\text { plication (van Rheede 1682) }\end{array}$ \\
\hline & $\begin{array}{l}\text { used as part of a camphorated poultice for } \\
\text { the treatment of swelling of testicles originat- } \\
\text { ing from contusion. (A folk medicine in north- } \\
\text { ern Kerala) }\end{array}$ \\
\hline \multirow[t]{2}{*}{ seeds } & $\begin{array}{l}\text { roasted with crushed onion fried in yogurt and } \\
\text { inserted rectally to treat constipation. (van } \\
\text { Reede } 1682 \text { ) }\end{array}$ \\
\hline & laxative (Agarwal 1986) \\
\hline seed oil & appetite stimulant (Agarwal 1986) \\
\hline wood & $\begin{array}{l}\text { used as a substitute for wood of Strychnos } \\
\text { nux-vomica L. for making 'oil massage cot' } \\
\text { popularly known as ennathoni (wooden ves- } \\
\text { sel for Ayurvedic oil massage) for the 'pan- } \\
\text { chakrma' treatment. (Ayurvedic medicine } \\
\text { practiced in Kerala) }\end{array}$ \\
\hline
\end{tabular}

\section{Agricultural uses}

The mature ripened fruit of $A$. hirsutus are pleasantly sweet and edible. Villagers prepare the roasted seeds like chestnuts and eat them as snacks.

The leaves of $A$. hirsutus were widely used on the Malabar coast for making green manure and compost, especially in paddy cultivation. However, the leaves are rarely used as fodder for cattle or goats in interior villages. At higher altitudes in Kerala the trees are used as support for pepper vines. 

Malabar Coast of South India

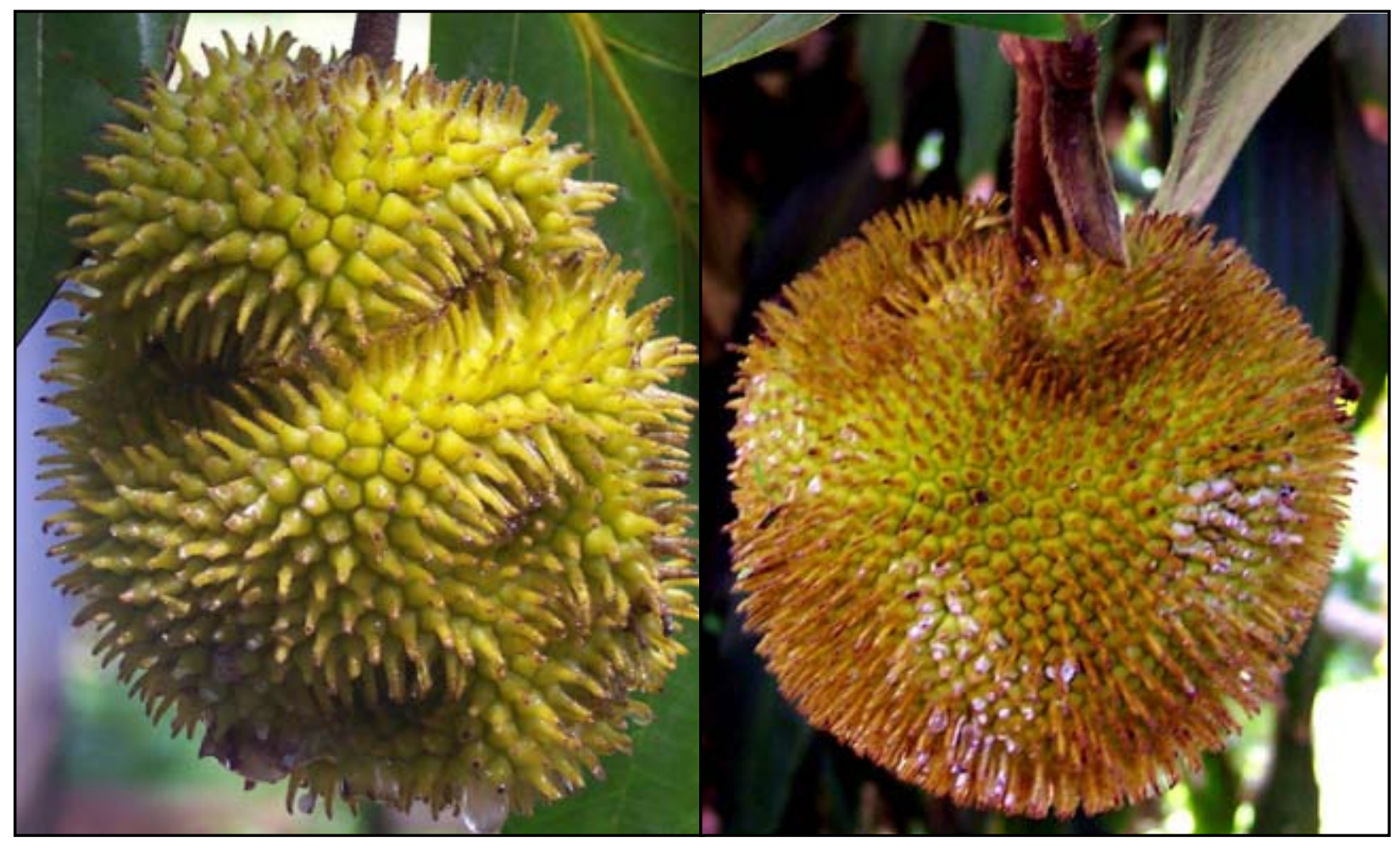

Figure 10. Intra specific variations in fruits of the wild jack tree.

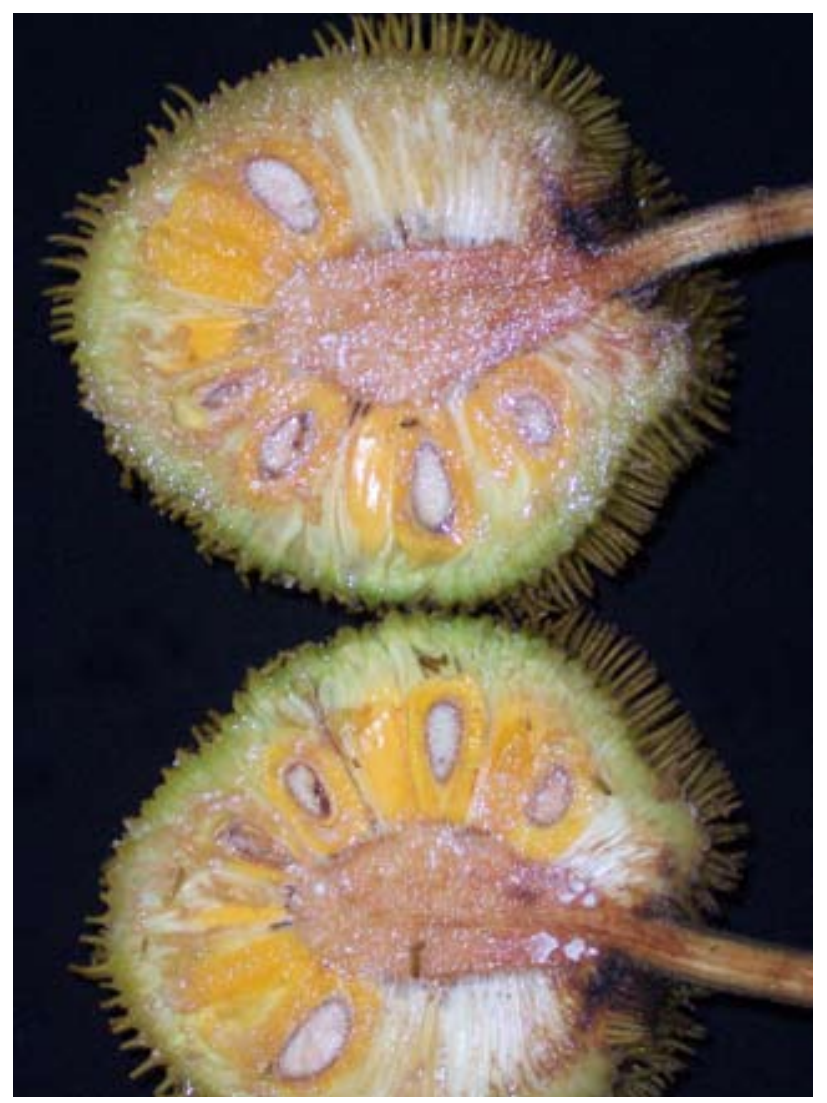

Figure 11. Longitudinal section of a mature fruit.
Artocarpus hirsutus is widely employed as a superior rootstock with $A$. altilis (breadfruit) stems grafted onto it to produce better quality fruit

\section{Timber value and cultural diversity}

According to historic data of the Malabar coast (16th to the mid 20th century), timber woods have much influenced

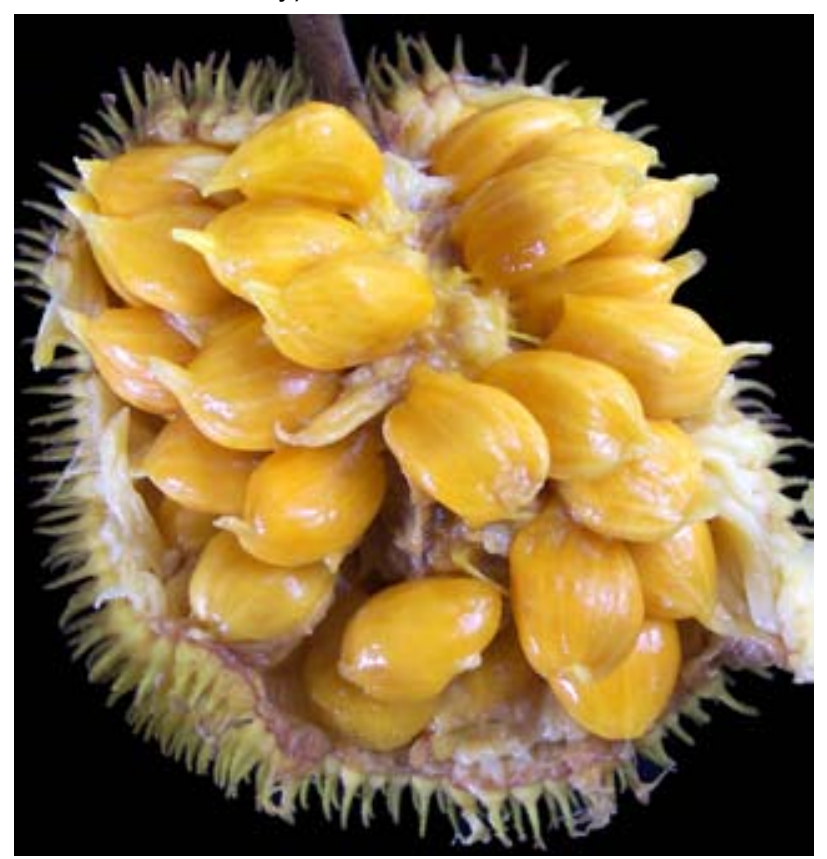

Figure 12. Ripe fruit.

www.ethnobotanyjournal.org/vol4/i1547-3465-04-025.pdf 


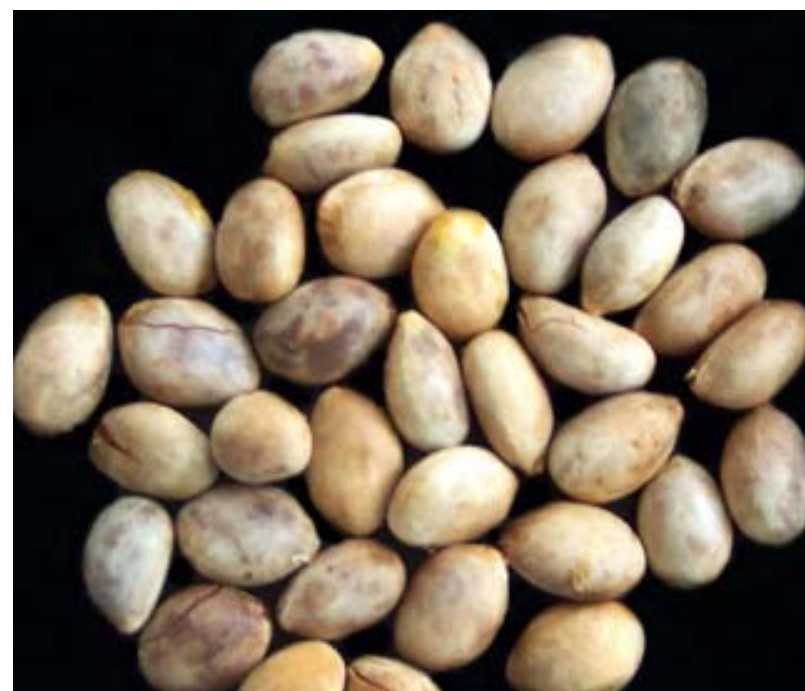

Figure 13. Mature seeds.

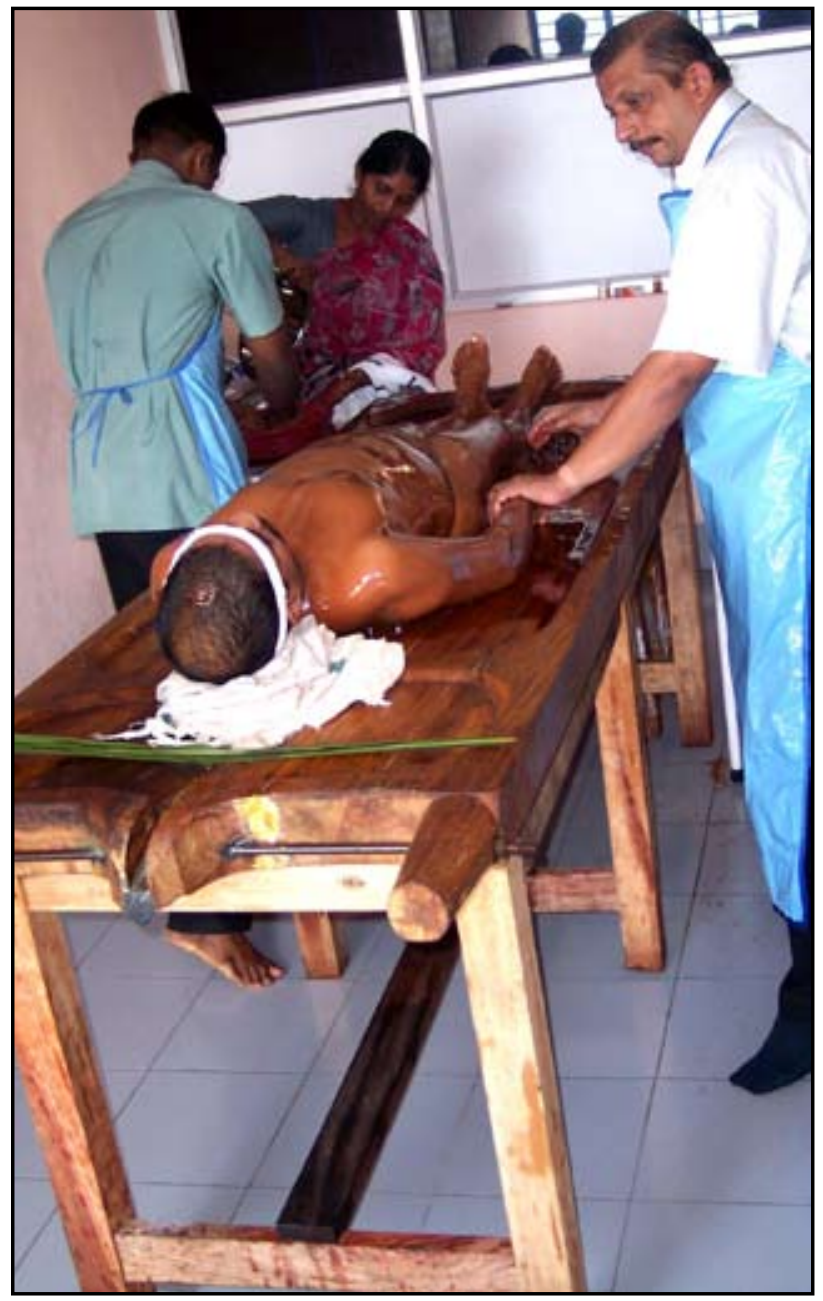

Figure 14. An Ayurvedic physician carrying out oil massage on ennathoni (massage table) made of wild jack wood. the expression of cultural diversity of Keralites particularly in construction (roofing, foundations, walls and floor of temples, palaces and mansions). Construction materials mostly consisted of wood from two species: $A$. hirsutus and $A$. heterophyllus. The "wood age" culture also promoted the rise of indigenous expertise for making murals on wood, especially wooden walls and tops of temples and palaces. Expertise has been steadily lost during the latter half of 20th century owing to the non-availability of timber trees (Nayar 1999). However, wild jack wood is still widely used for making frames of doors and windows. Planks

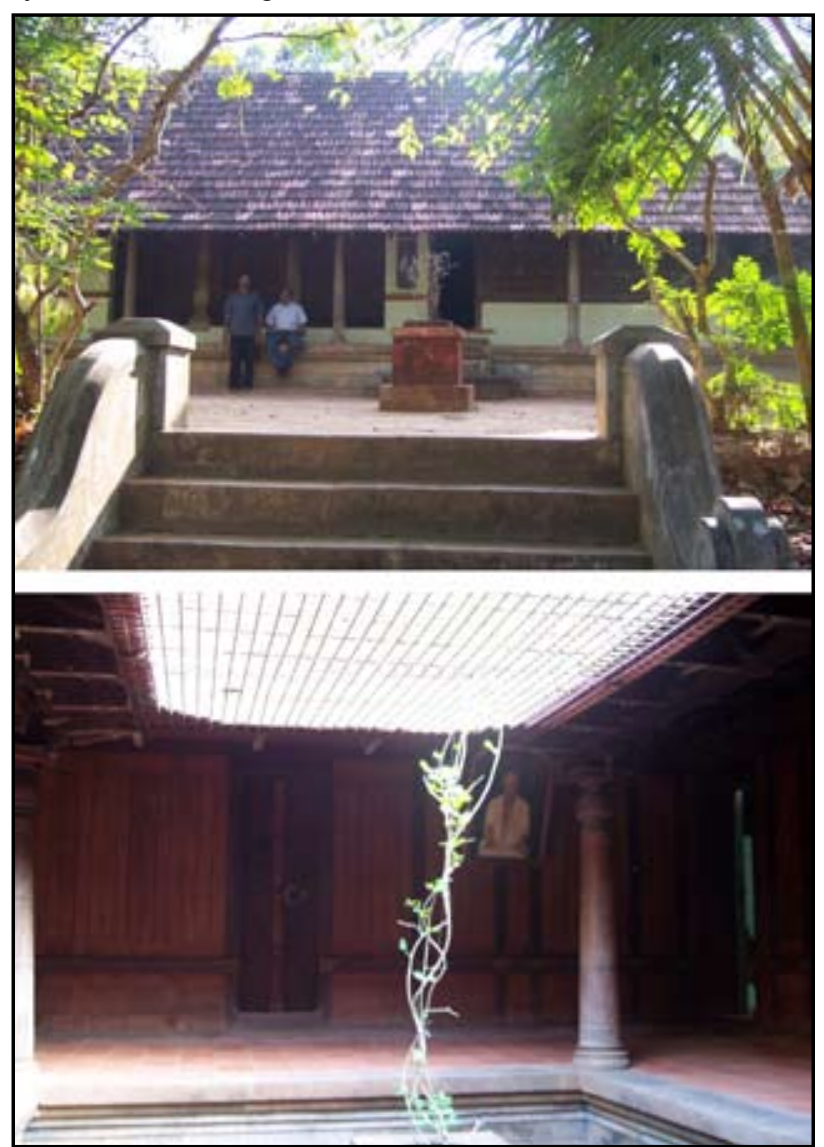

Figure 15. A traditional building (nalukettu) made of wild jack wood with wooden pillars and walls.

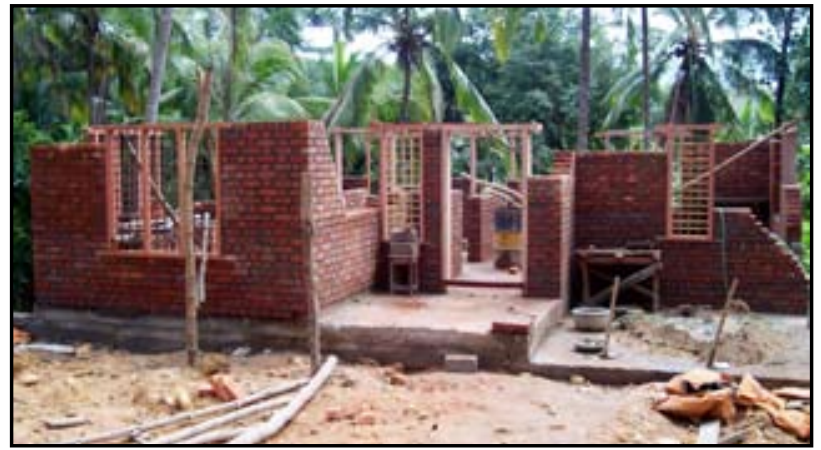

Figure 16. A modern construction with doors and window frames made of wild jack wood. 

Malabar Coast of South India

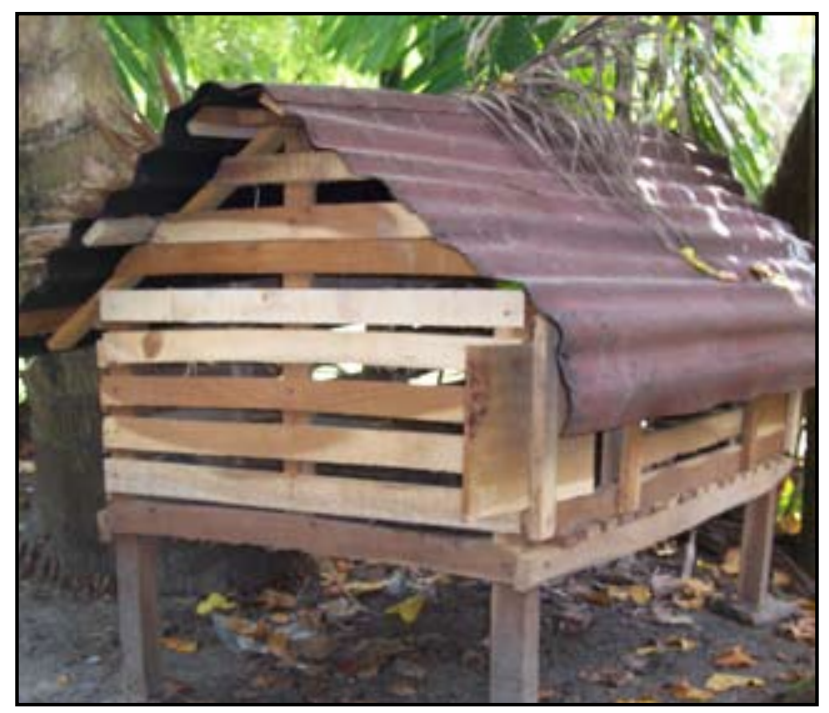

Figure 17. A poultry cage common in villages, made of wild jack wood reapers.

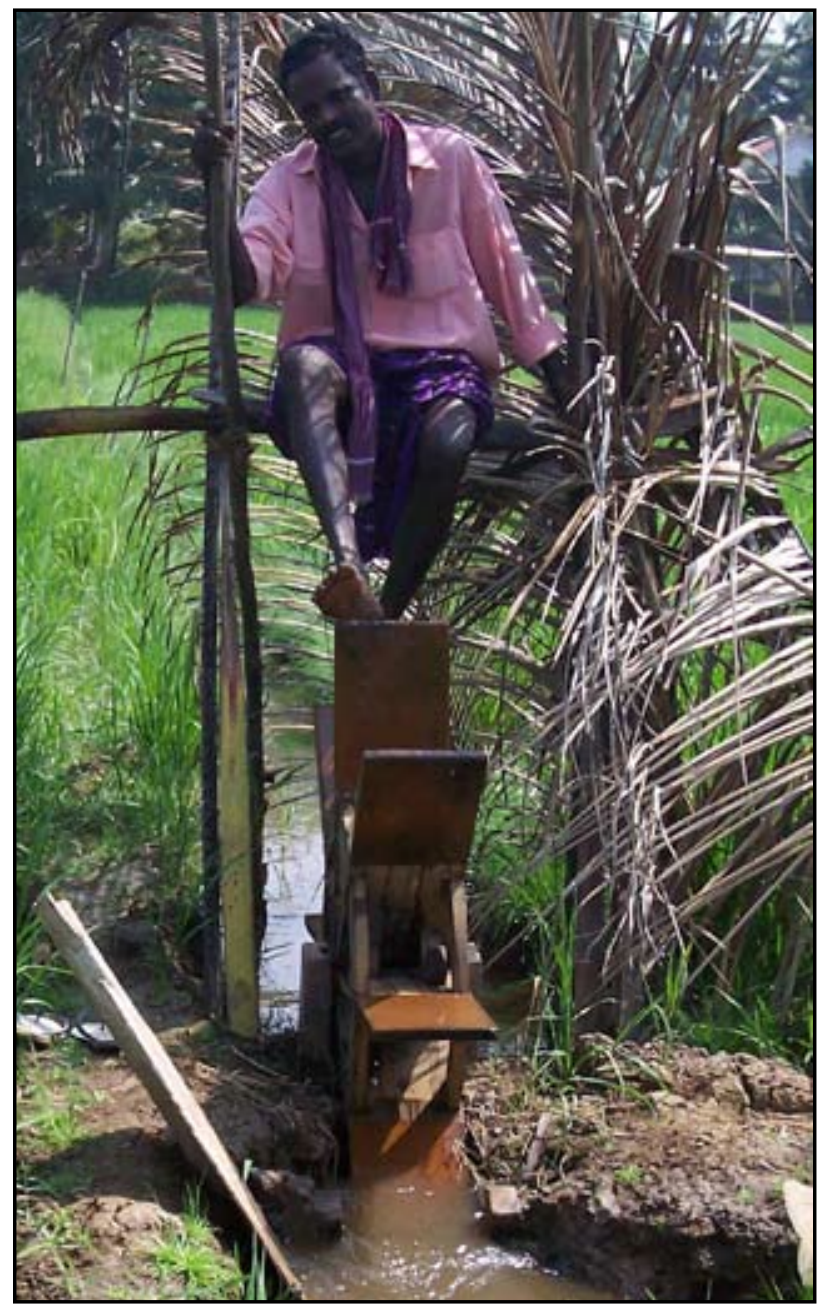

Figure 18. Chackrum (water tread wheel for controlling irrigation in paddy cultivation) made of wild jack wood.

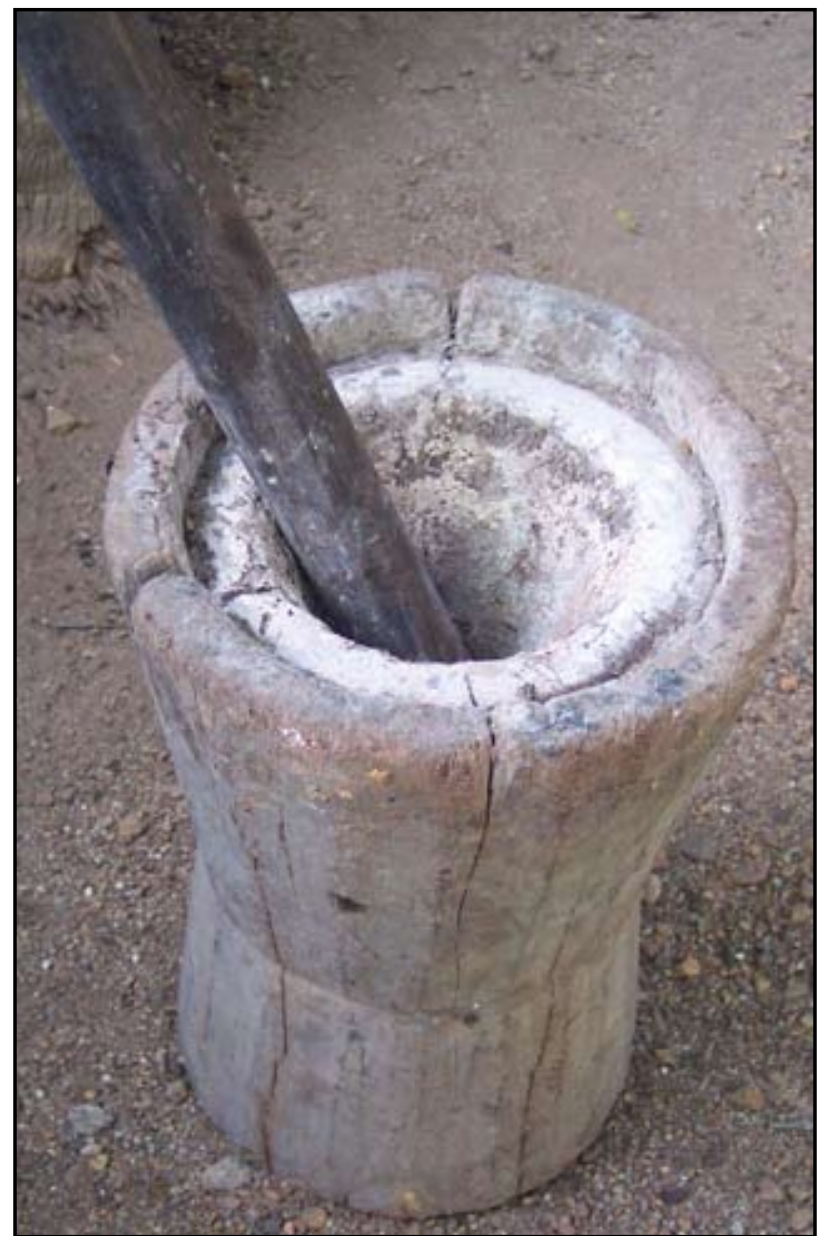

Figure 19. Ural (pounding vessel) made of wild jack wood.

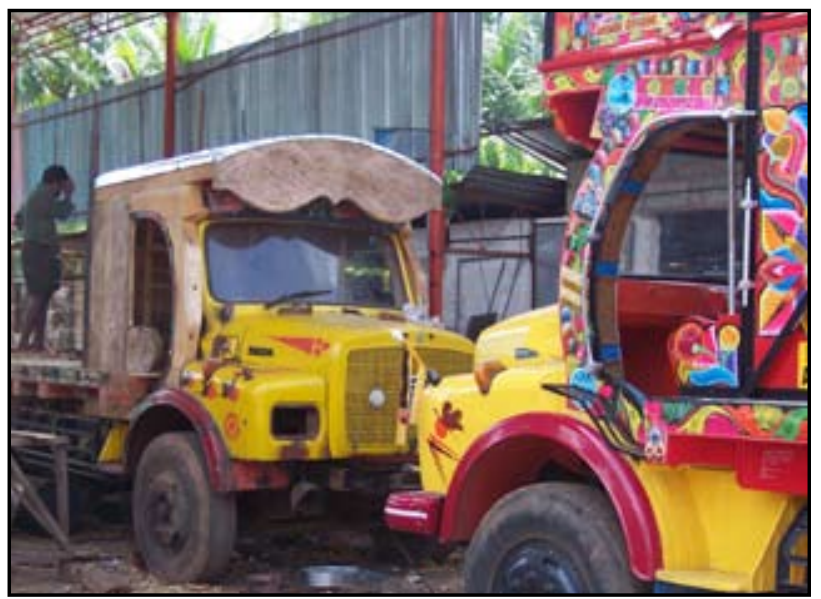

Figure 20. Body building of trucks by wild jack timber in a local work shop.

and beams of wild jack tree are traditionally being used for conventional roofing and false ceilings of ordinary houses and other buildings. The timber was very popular for use (along with teak and rosewood) for giant wooden pillars and beams used in the construction of Naalukettu and 
Ettukettu (traditional mansions of earlier landlords along the Malabar coast). The wood is also exclusively used for the construction of traditional giant granaries to keep paddy grains associated with naalukettu and ettukettu. Because of its water resistence and durability the wood was also used for making cisterns in houses and utensils such as ural (used for pounding grain) and maravi (a wooden vessel for keeping common salt pellets for cooking) However, ural and maravi are presently uncommon and have vanished from the houses of Keralites. The wood is considered the best for yolks and chackrum (traditional water tread wheels) that are used to regulate water flow in paddy fields. The wood is also used to make poultry cages. Finally, the wood was one of the popular timbers of the Indian Railway for construction of railway sleepers a few decades back and continues to be used in construction of handmade truck cabs.

\section{Ship and country boat-building}

Arguably the most important use of wild jack wood timber has been in the production of ships and boats. Fiftyone kinds of boats under three categories, 1) rafts, 2) dugout and 3) plank built, have been recognized from Kerala

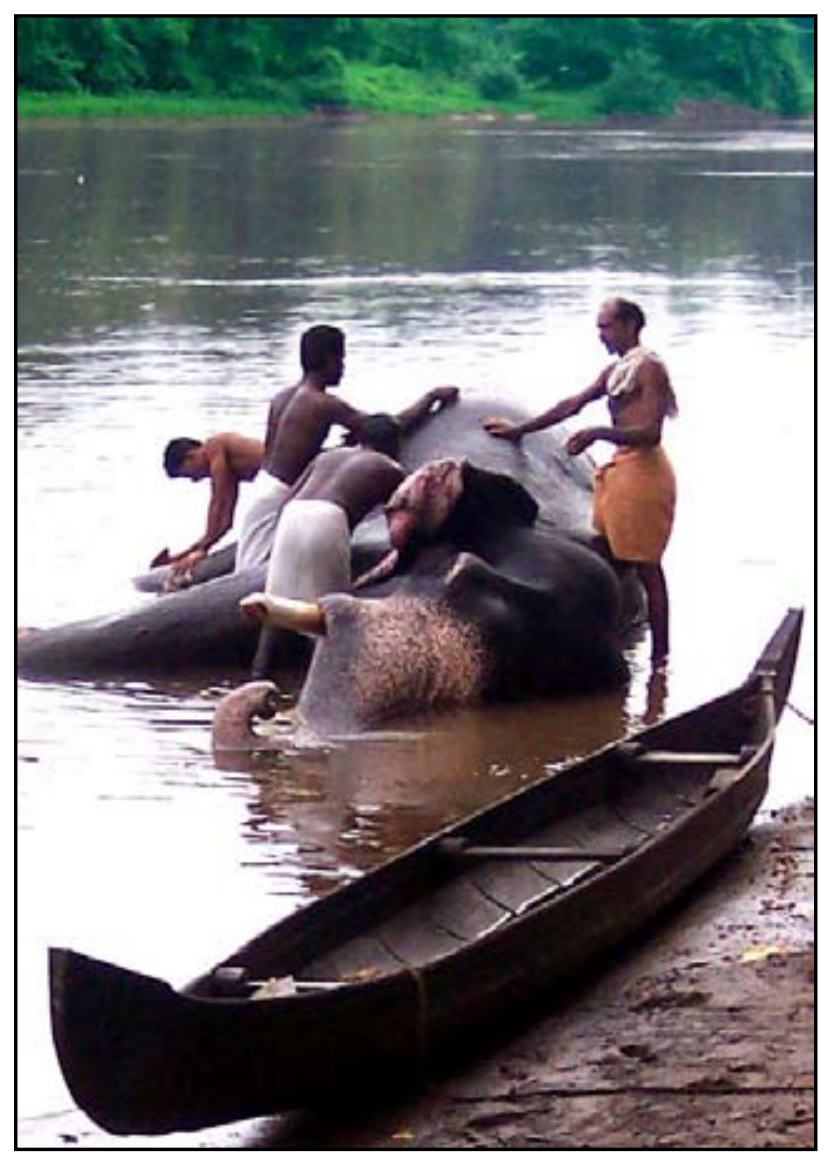

Figure 21. A small country boat used for ferry service - A common view from a river side in central Kerala.
(Greeshmalatha \& Rajamanickam 1993). Plank built boats may be nailed or stitched. The wild jack is the most common timber used for the make of traditional nailed plankbuilt boats. Among the kinds of plank built boats used for various purposes are maccua and vallam (travel boats), uru (small cargo boats), kovallam (large cargo vessels), palliyodam (ritual boats used in some Hindu temples as part of New Year festivals), and chundan, churulan, odi, iruttukuthy (snake boats or country race boats).

Kothumbu vallam is a masterpiece in country boat making of Central Kerala. These are perhaps the smallest

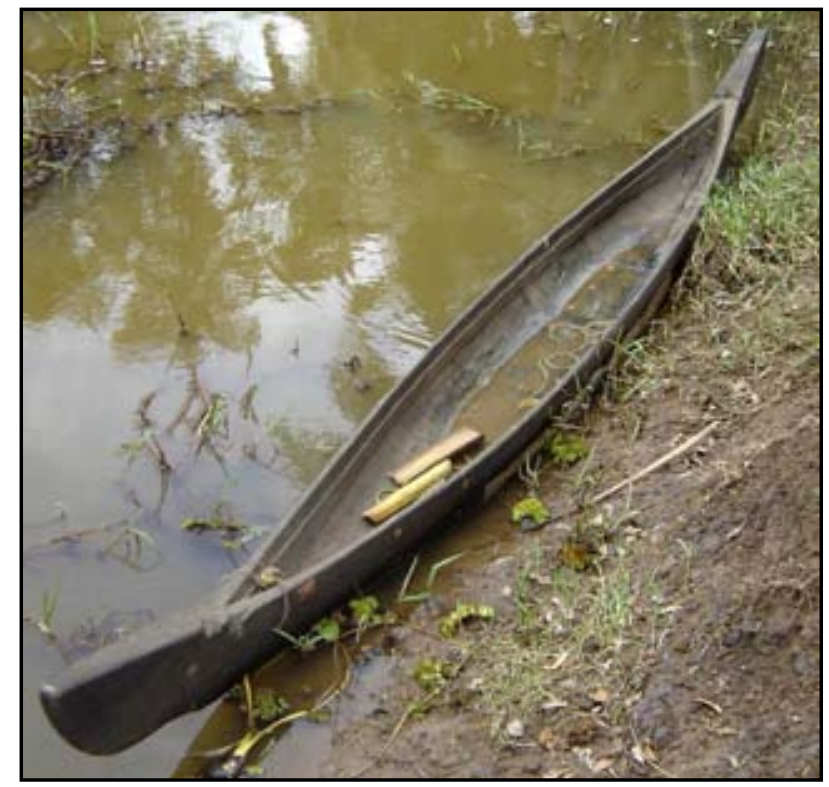

Figure 22. Kothumbu vallam (the smallest dug-out country boat of the Malabar Coast).

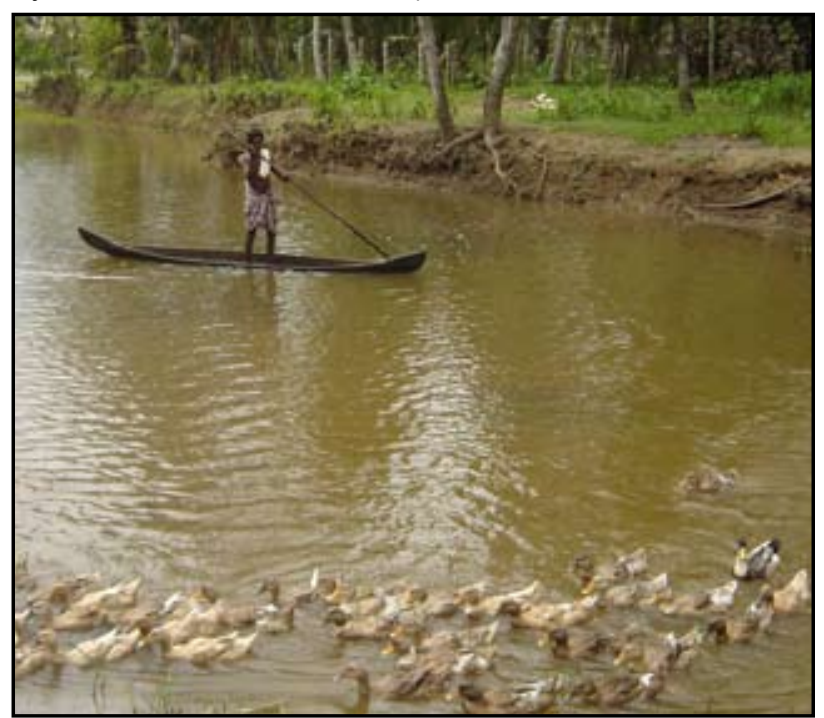

Figure 23. A farmer of central Kerala feeding his ducks in a flooded paddy field by using his kothumbu vallam. 

Malabar Coast of South India

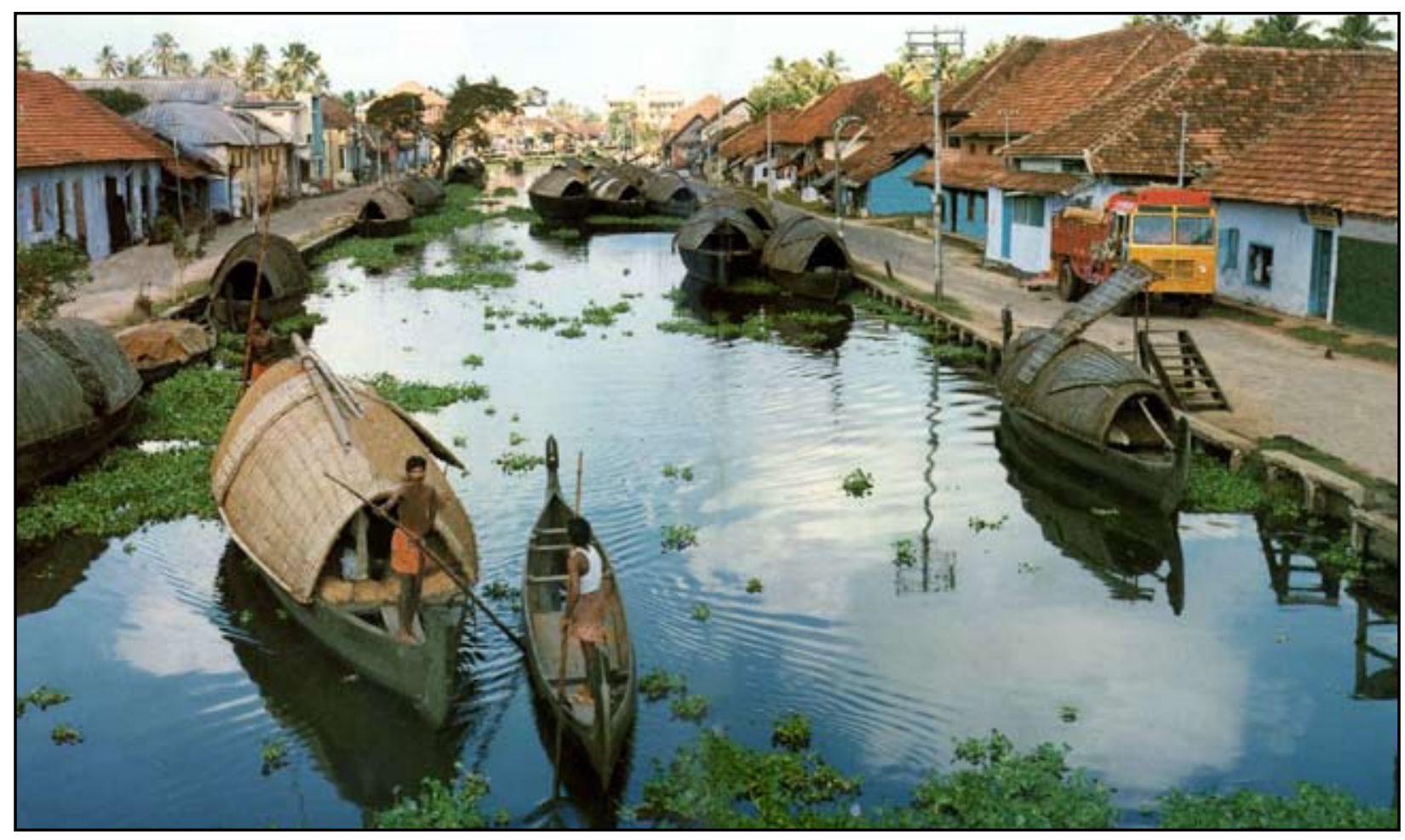

Figure 24. A view of cargo boats (likely made of wild jack wood) from a few decades ago trading at Alleppey, central Kerala.

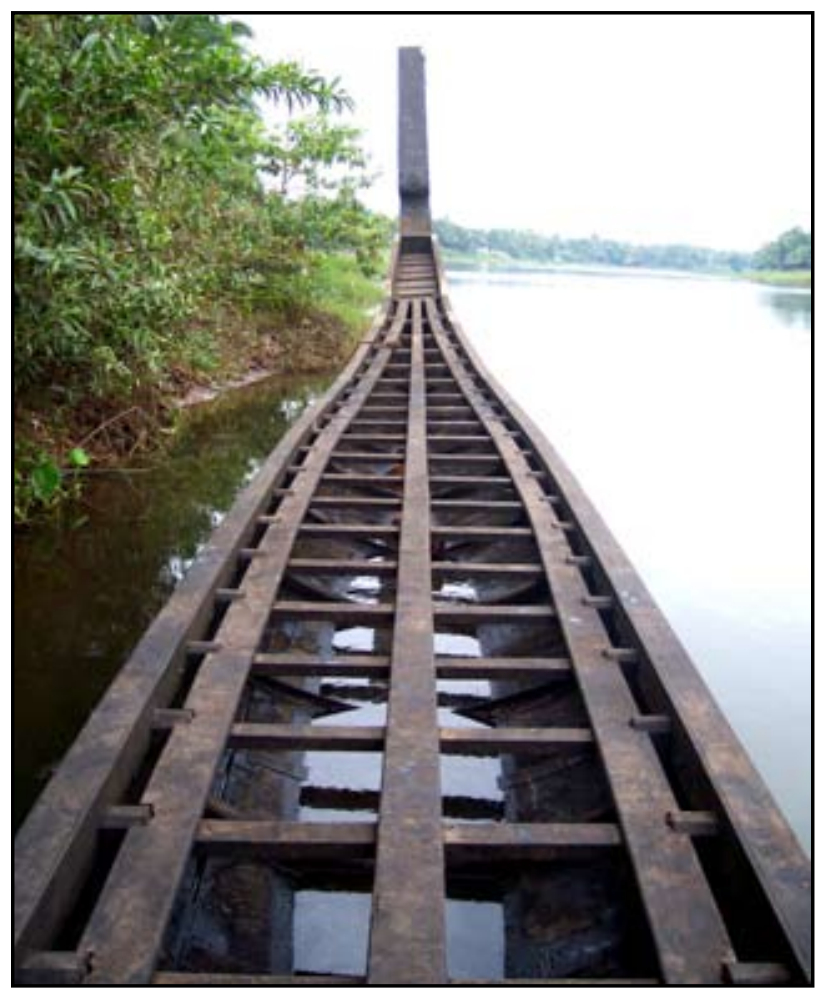

Figure 25. A snake boat constructed of wild jack wood in central Kerala.

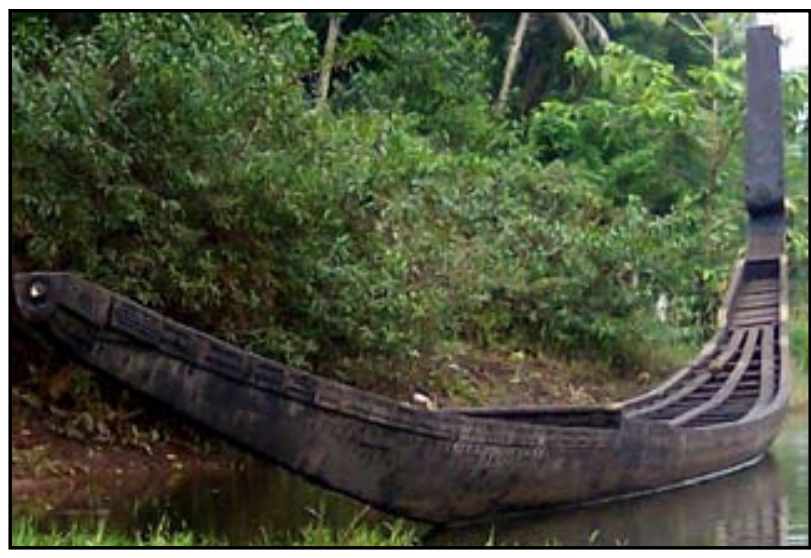

Figure 26. A snake boat used for country boat races on back waters in central Kerala.

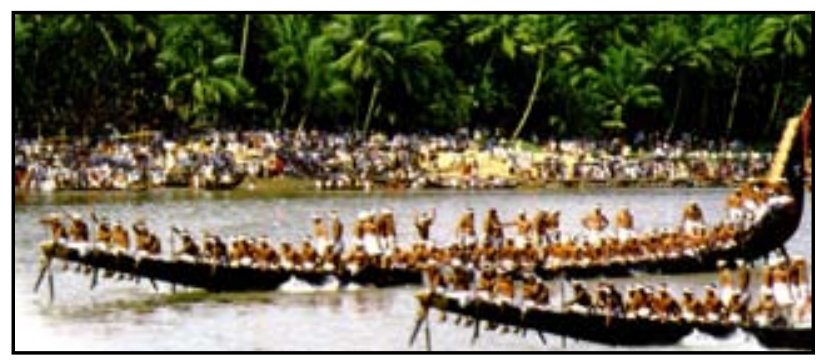

Figure 27. A picturesque view of a snake boat race on backwaters in central Kerala. 
(dug-out) country boats from giant boles of $A$. hirsutus and Hopea parviflora Bedd., without any joints or nails as in plank-built boats. Duck farming is a common practice among the villagers of the Central Kerala and this kind of small county boat was widely used until a few decades ago, to feed ducks in back waters and flooded paddy fields after the harvest. Kothumbu vallam were once common in back waters of Alapuzha district but are now replaced by small fiberglass boats. Similarly, kovallam, once very common in rivers and lakes of Kerala have now been converted into luxury 'house boats' for back water tourism. The recent archaeological excavation of an inland cargo vessel about one kilometer away from the coast of central Kerala at Alapuzha District has illustrated that the age of the wild jack wood used for the construction of the vessel dates between AD 920 and 1270 by radiocarbon dating techniques (Nair et al. 2004). It indicates the use of wild jack tree for shipbuilding was common in the state for at least several centuries.

The Malabar coast was very famous for construction of traditional two-masted cargo vessels called pattamar or pattimar (The terms are derived from the Protégé word pataxopinnace). Pattamar are the traditional masterpieces of the people of Baipur in Northern Kerala. The pattamar of Baipur were famous in Europe and the Middle East for centuries. The major timber used for the construction of

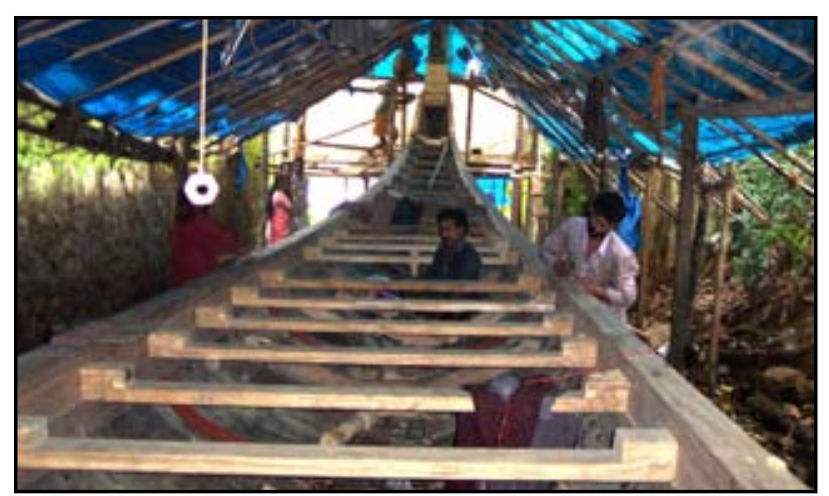

Figure 28. A new construction of a snake boat.

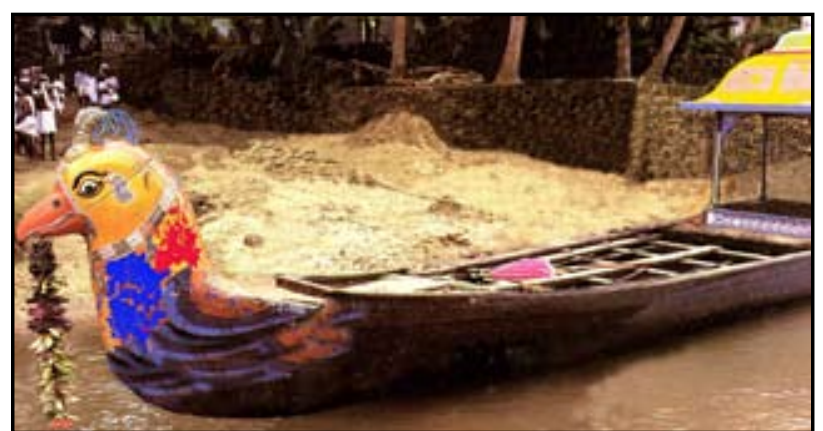

Figure 29. Aranmula palliyodum (ritual boat) made of wild jack wood associated with Hindu temple at Aranmula in central Kerala. the pattamar in those days was the wild Jack tree. Country boats and vessels for various uses including travel, cargo, fishing, and other cultural and religious purposes have long been popular in Kerala.

\section{Miscellaneous uses}

The latex has an insect repellant property and in some places of the Malabar coast, it is used as wood coating to prevent insect attack. The wood, wood peelings, small branches and stumps of the tree may be used as fire wood or fuel because of their good calorific value.

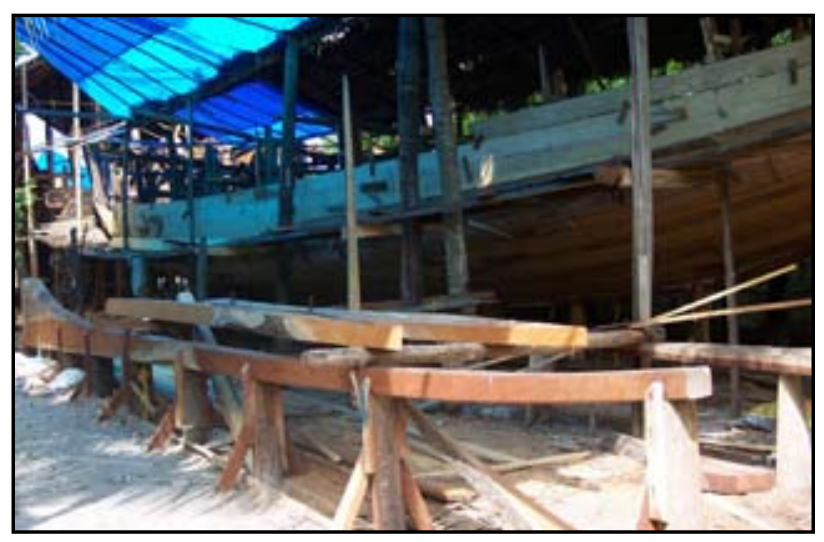

Figure 30. Construction of a large fishing boat.

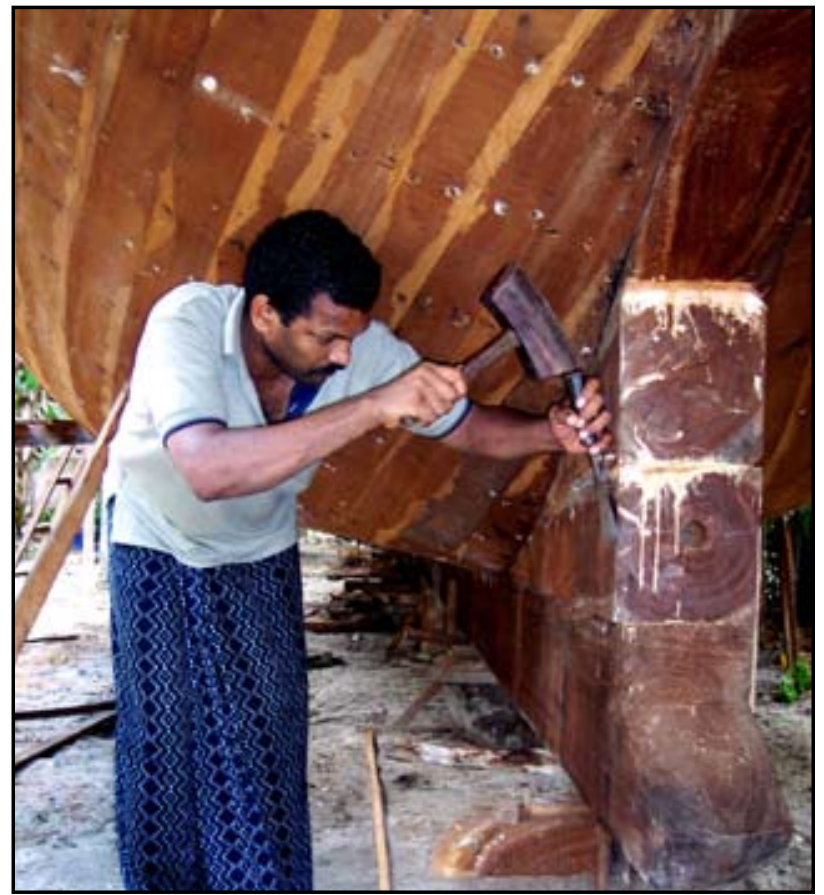

Figure 31. Construction of a large fishing boat keel. 

Malabar Coast of South India

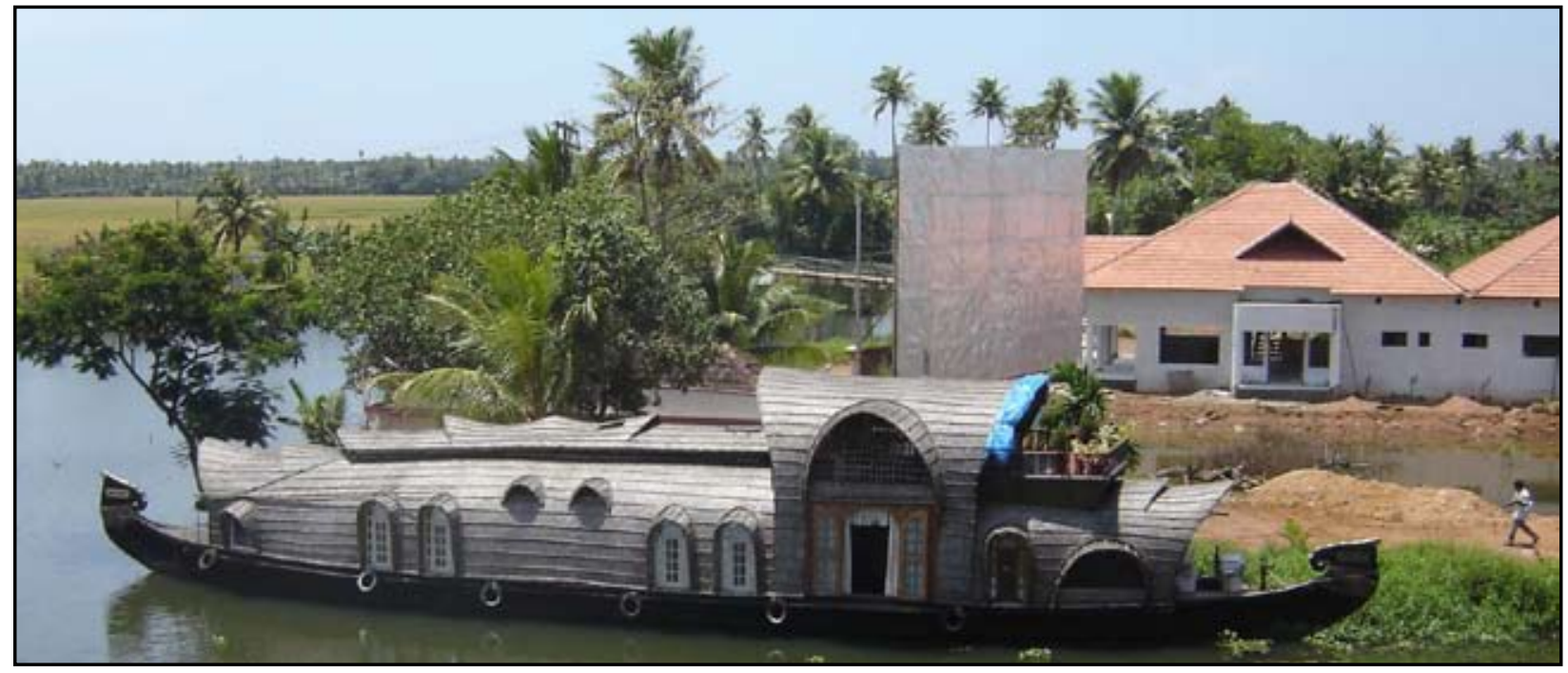

Figure 32. An old cargo boat of wild jack wood converted into a luxury house boat as viewed from Alappuzha.

\section{Present Status and} Conservation Scenario

Even though the tropical rain forests occurring on the slopes of the southern Western Ghats are disturbed, this species is not yet critically endangered. However, the current availability of mature jack trees probably cannot meet its present domestic demand and the value of wild jack timber is high in the timber market. This indicates that the species will likely become more and more rare unless effective efforts are taken for its conservation and sustainable utilization. Even though the wild jack tree has remarkable popularity and utilities, it has not been consid- ered for commercial plantations such as is the case with teak. Currently, an area of about 10 hectares of wild jack plantation at Palode range in Thiruvananthapuram District of the Kerala Forest Department planted during the latter half of 1950s and earlier part of 1960s is the only known plantation in Kerala. No effective endeavor has been considered for propagation and cultivation of this species that is in such high demand.

\section{Sacred groves}

The sacred groves of Kerala had a key role in conservation of several huge trees, which include A. hirsutus. However, it can be observed that the healthy natural growth of

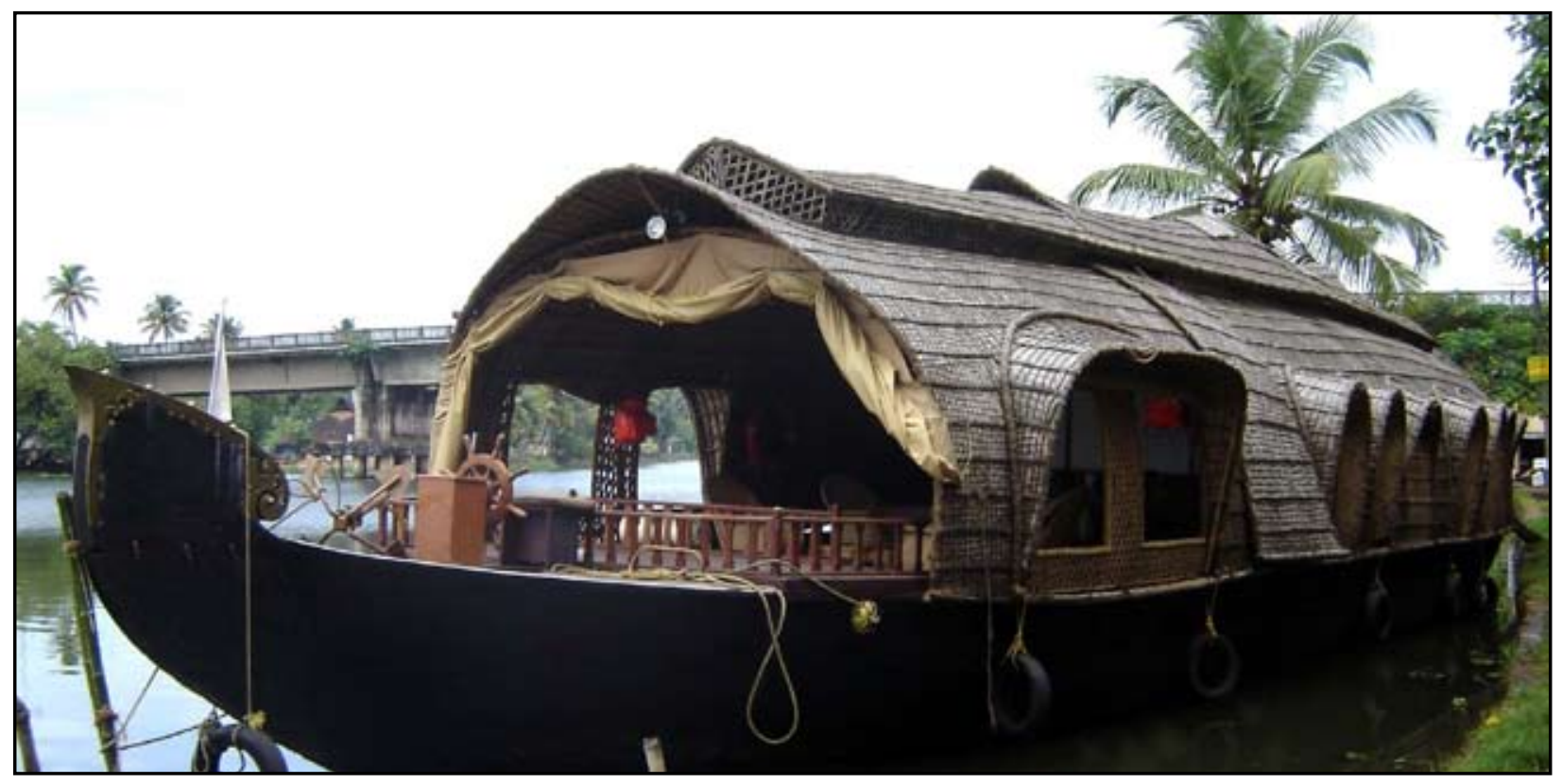

Figure 33. A luxury air-conditioned house boat made with a wild jack wood hull. 
this species in sacred groves seems to be very poor owing to the abortion of apical meristems in seedlings, which culminates with the growth of one or two axillary buds (Rajendraprasad 1995). This character is a shade adaptation of the species. Destruction of sacred groves due to various reasons has accelerated the decline of several trees. Younger generations of people have deviated from their traditional faith and worship and are least concerned with routine worship of the deities in these groves. Several sa-

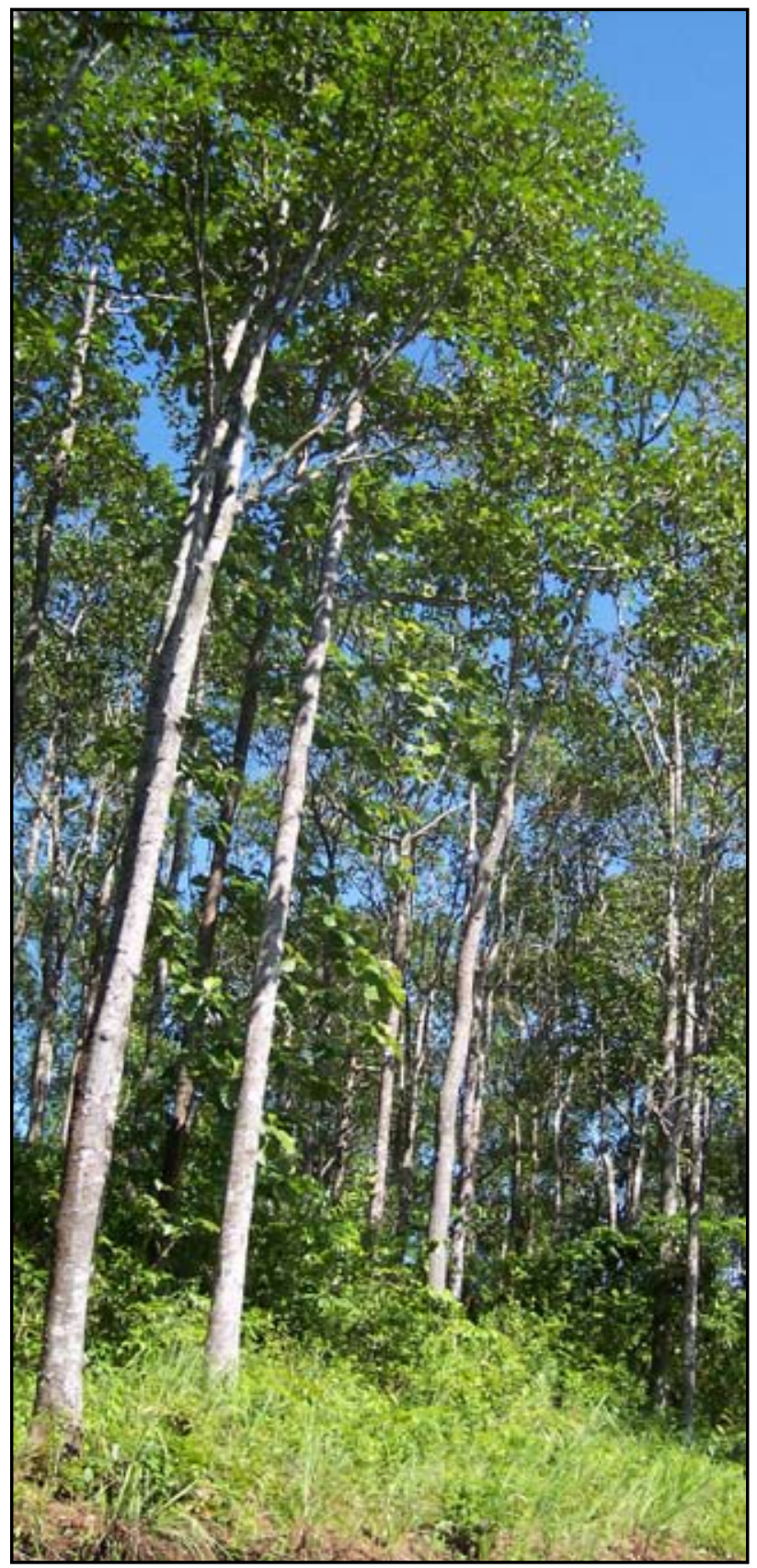

Figure 34. A view of Artocarpus hirsutus plantation at Palode, Trivandrum. cred groves in Kerala have already disappeared or are on the verge of extinction owing to construction of buildings, roads, power lines, plantations, etc. However, several sacred groves still remain undisturbed or little least human interference and therefore conserve several huge trees of this species.

\section{Urbanization}

The rapid urbanization in parts of the state recently also have had severe impacts on this species. Widening of roads and construction of new buildings has brought about felling of enormous wild jack trees and ruthless destruction of their seedlings in the vicinity.

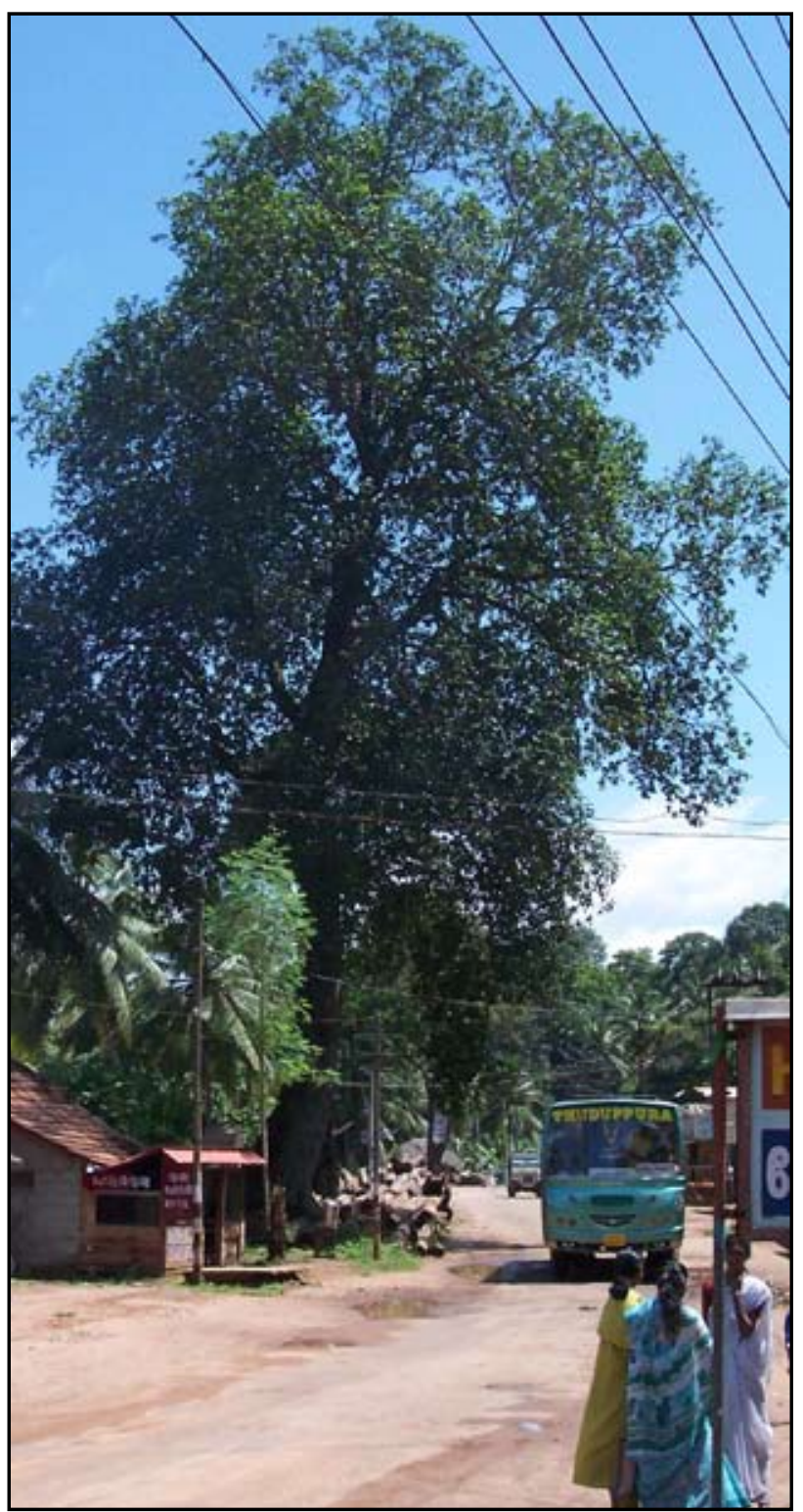

Figure 35. A giant wild jack tree along the way side that is under threat on road widening. 


\section{Mathew et al. - Biocultural Diversity of the Endemic 'Wild Jack Tree' on the Malabar Coast of South India}

According to current statistics, the population density in Kerala is over 700 per $\mathrm{km}^{2}$., which is four times greater than the Indian average (182 per $\mathrm{km}^{2}$ ) indicating the limitation of the land area. Presently, the whole state can be considered as a metro city and earlier villages and country sides have vanished in the course of urbanization.

\section{Family concepts and economics}

The modern family concept, as a change in the cultural values of Keralites, also has had deleterious effects on this species from several homesteads. The extended (joint) family system was very popular in Kerala two or three generations ago. Parents, children and their families stayed together in the same house and agriculture in parental land holdings was the main source of income generation.

During recent decades, literacy and educational status of Keralites has become elevated and people have migrated to the Middle East, Europe and United States for jobs. Educational status and influx of foreign money has contributed to changes in living standards and family concepts of Keralites. The improvement of economic status and the concept of nuclear families with independent houses rather than the earlier joint family system with single residential house have seriously accelerated felling operation. The construction of independent houses for each family in a joint family which once had stayed together in a common house, had enforced to divide the common paternal land holdings into several partitions and had to cut several trees growing in the home yard for space and construction of houses.

This change in cultural diversity of Keralites has severely affected the existence of popular native trees of the homesteads such as $A$. hirsutus, $A$. heterophyllus and Mangifera indica $\mathrm{L}$. The division of paternal land holdings into several partitions and construction of independent houses for each nuclear family has limited people's abilities to conserve and maintain huge trees like $A$. hirsutus within homesteads. The limited area of land holdings of each family has also limited the reintroduction of saplings of these huge trees. Both illegal felling and legal extraction of $A$. hirsutus from wild resources has also depleted the natural regeneration of the species. Unwise conservation practices have also lead to depletion of wild jack trees, especially in a portion of the wild jack plantation at Palode range. The large introduction of Acacia auriculiformis A. Cunn. ex Benth., an exotic species in this plantation area will certainly deplete the healthy natural regeneration of this species.

\section{Conclusions}

Artocarpus hirsutus is perhaps the only endemic wild tree species with such remarkable influence on cultural diver- sity of the people along the Malabar coast. Although this paper has not presented quantitative analysis of either the trees or traditional uses of the trees, our observation from working in Kerala with these trees over many years are that most of the indigenous knowledge attributed to this species appears to be vanishing and presently is poorly known. The traditional technical know-how of pattamar and snake boat building is confined to a few people of the earlier generations. It appears that this is least known to the present generation. Similarly, the carpenters expertise in construction of naalukettu and ettukettu is probably diminishing. The jack wood ural and maravi once common in all houses of the Malabar coast have almost vanished. Similarly, the traditional yolks, water wheels, granaries and cisterns have already been replaced by mechanized cultivation and modern methods of storage. The traditional knowledge of making agriculture implements, granaries, etc. is also least known to the carpenters of present generation. Most of the medicinal uses of the species are presently confined to only a few tribal communities of Kerala.

Unlike teak, no advanced research seems to have been carried out on $A$. hirsutus as a crop. Quality improvement of wood by any agency is desperately in need. Fortunately, the species has not become popularized beyond the southern Western Ghats region. Advanced research and forestry experiments on this species and its popularization in tropical habitats would certainly be rewarding and lead toward prevention of its local loss. This would also potentially enable retention of the traditional knowledge associated with the trees.

\section{Acknowledgements}

The authors record their sincere thanks to Prof. (Dr) K. G. Gopalakrishnan, Dr Binoj Kumar and Dr Sreedevi, S. D College, Alapuzha for technical help to make anatomical sections and to the Kerala Forest Department relevant information and library facilities. Sincere thanks also to Dr J L Ellis, Bangalore for necessary encouragements on right time in preparation of this article.

\section{Literature Cited}

Agarwal, V.S. 1986. Economic Plants of India. Kailash prokasan, Calcutta.

Ahmedullah, M. \& M. P. Nayar. 1986. Endemic Plants of Indian Regions. Botanical survey of India, Calcutta.

Anonymous. 1974. Malayalam Encyclopaedia Volume 2: 699-700. Malayalam Encyclopaedia department, Trivandrum.

Bible. 1984. Bible. New International Version. Zondervan Publishing, Grand Rapids, Michigan. 
Bourdillon, T.F. 1892. Report on the Forest of Travancore. Travancore Government Press, Trivandrum.

Geetha, S., G. Lakshmi \& P. Ranjithakani. 1996. Ethno veterinary Medicinal Plants of Kolli Hills, Tamilnadu. Journal of Economic and Taxonomic Botany (Ad. Ser.) 12: 289 -291 .

Greeshmalatha, A.P. \& G.V. Rajamanickam. 1993. An analysis of different types of traditional coastal vessels along the Kerala coast. Journal of Marine Archaeology 4: 36-51.

Hegde, M., S. Sekaran, K. Sivabalakrishnan, B. Singh, B.G. Palanisamy, K. Siddappa, 2003. Establishment of seed production area of Artocarpus hirsutus in Kerala. Indian Forester 129:1470-1478.

Maheswar, H., S. Sekaran, K. Sivabalakrishnan, B.G. Singh, K. Palanisamy \& V. Mani. 1964. Puranic Encyclopedia. Current Books, Kottayam, India.

Manilal, K.S. 2003. Hortus Malabaricus (English edition) University of Kerala, Thiruvananthapuram. 3: 49-52.

Nair, P.N. \& C.S. Nair. 1985. 'Keralathile Vanasasyangal' (Forest Plants of Kerala). State Institute Languages, Kerala.

Nair, M.V., V. Selva Kumar \& P.K.Gopi. 2004. Excavation of a unique sail boat at Kadakkarapally, Kerala, Current Science 86: 709-712.

Nayar, M.P. 1996. Hot Spots of Endemic Plants of India, Nepal and Bhutan. Tropical Botanic Garden and Research Institute, Trivandrum, India.

Nayar, M.P., K. Ramamurthy \& V.S. Agarwal. 1989. Economic Plants of India. Botanical Survey of India, Calcutta.

Nayar, T.S., S. Binu \& P. Puspangadan. 1999. Uses of plants and plant products in traditional Indian mural paintings. Economic Botany 53: 41-50.

Panikkassery, V. 2001. Sancharikal kanda Keralam (A historical literature on Kerala in the Malayalam language) DC Books, Kottayam.

Parinitha, M, G.U. Harish, N.C. Vivek, T. Mahesh \& M.B. Shivanna. 2004. Ethno-botanical wealth of Bhadra Wildlife Sanctuary in Karnataka. Indian Journal of Traditional Knowledge 3: 37-50.

Pearson, R.S. \& H.P. Brown. 1932. Commercial Timbers of India. Their Distribution, Supplies, Anatomical Structure, Physical and Mechanical Properties and Uses. Vol- ume II. Government of India, Central Publication Branch, Calcutta.

Rai, S.N. 1978. Nursery and Planting of Some Tropical Evergreen and Semi-Evergreen Species. Silviculturist, SZ, Karnataka Forest Department, Madikeri.

Rajashekharan, S. \& P. Pushpangadan. 1993. Indigenous taxonomy of plants according to 'Samhitas' and 'Nighandus'. Aryavaidyan 6:182-188.

Rajendraprasad, M. 1995. The Floristic Structural and Functional Analysis of Sacred Groves of Kerala. Ph. D thesis, University of Kerala, Thiruvananthapuram.

Ramesh, B.R. \& J.P. Pascal. 1997. Atlas of Endemics of the Western Ghats (India). Institute Francais de Pondichery, Pondicherry.

Rheede tot Drakestein, H.A. van. 1682. Hortus Indicus Malabaricus Bishen Singh and Mahendrapal Singh, Dehra Dun. 3:25-27, t.32. 